\title{
Isotopic evidence for the occurrence of biological nitrification and nitrogen deposition processing in forest canopies
}

\begin{tabular}{|c|c|}
\hline Journal: & Global Change Biology \\
\hline Manuscript ID: & Draft \\
\hline Wiley - Manuscript type: & Primary Research Articles \\
\hline Date Submitted by the Author: & $\mathrm{n} / \mathrm{a}$ \\
\hline Complete List of Authors: & $\begin{array}{l}\text { Guerrieri, Rossella; University of New Hampshire, Earth Systems Research } \\
\text { Center } \\
\text { Vanguelova, Elena ; Forest Research, Centre for Forestry and Climate } \\
\text { change } \\
\text { Michalski, Greg; Purdue University, Department of Earth, Atmospheric, and } \\
\text { Planetary Sciences } \\
\text { Heaton, Timothy; British Geological Survey, NERC Isotope Geosciences } \\
\text { Laboratory } \\
\text { Mencuccini, Maurizio; University of Edinburgh, School of GeoSciences; } \\
\text { ICREA, CREAF }\end{array}$ \\
\hline Keywords: & $\begin{array}{l}\text { Nitrogen deposition, canopy nitrification, d15N, d180, D170, NH4-N, NO3- } \\
\mathrm{N} \text {, forest canopy interception, Scots pine, beech }\end{array}$ \\
\hline Abstract: & $\begin{array}{l}\text { This study examines the role of tree canopies in processing atmospheric } \\
\text { nitrogen (Ndep) for four forests in the UK subjected to different Ndep } \\
\text { loads: Scots pine and beech stands under high Ndep (HN, } 13 \text { and } 19 \mathrm{~kg} N \\
\text { ha-1 yr-1, respectively), compared to Scots pine and beech stands under } \\
\text { low Ndep (LN, } 9 \mathrm{~kg} N \text { ha-1 yr-1). Changes of NO3-N and NH4-N } \\
\text { concentrations in rainfall (RF) and throughfall (TF) together with a } \\
\text { quadruple isotope approach, which combines } \delta 180, \Delta 170 \text { and } \delta 15 \mathrm{~N} \text { in } \\
\text { NO3- and } \delta 15 \mathrm{~N} \text { in NH4+, were used to assess N transformations within the } \\
\text { canopies. Generally, HN sites showed higher NH4-N and NO3-N } \\
\text { concentrations in RF compared to the LN sites. Similar values of } \delta 15 \mathrm{~N}- \\
\text { NO3- and } \delta 180 \text { in RF suggested similar source of atmospheric NO3- (e.g., } \\
\text { local traffic), while more positive values for } \delta 15 \mathrm{~N}-\mathrm{NH} 4+\text { at HN compared to } \\
\text { LN likely reflected the contribution of dry Ndep from intensive local } \\
\text { farming. The isotopic signatures of the N-forms changed during canopy } \\
\text { processing, although changes in ion concentrations between RF and TF } \\
\text { were significant only at the HN sites. } 15 \mathrm{~N} \text {-enriched NH4+ in TF compared } \\
\text { to RF at all sites suggested canopies played an important role in buffering } \\
\text { dry Ndep also at the low atmospheric } \mathrm{N} \text { load. By using } \Delta 170, \text { we could } \\
\text { prove for the first time that up to } 60 \% \text { of NO3- in TF at the HN sites } \\
\text { derived from nitrification occuring in tree canopies, with a higher fraction } \\
\text { in beech vs. Scots pine. Our study suggests that tree canopies do not play } \\
\text { a passive role in the } \mathrm{N} \text { cycling within forest ecosystems. Processing of Ndep } \\
\text { within canopies should not be neglected and needs further exploration, }\end{array}$ \\
\hline
\end{tabular}


with the combination of powerful tracers, i.e., $\Delta 170$, in order to better quantify the role of forests as sinks but also sources of $\mathrm{N}$.

\author{
SCHOLARONE ${ }^{m}$ \\ Manuscripts
}


1 Isotopic evidence for the occurrence of biological nitrification and nitrogen deposition

2 processing in forest canopies

3

4 Guerrieri $\mathrm{R}^{1,2}$, Vanguelova $\mathrm{E}^{3}$, Michalski $\mathrm{G}^{4}$, Heaton $\mathrm{THE}^{5}$, Mencuccini $\mathrm{M}^{2,6}$

5

6

1. Earth Systems Research Center, University of New Hampshire, Morse Hall, 8 College Rd, Durham, NH 03824, USA

2. School of GeoSciences, University of Edinburgh, Crew Building, West Mains Road, Edinburgh EH9 $3 J N, U K$;

3. Centre of Ecosystem, Society and Biosecurity, Forest Research, Alice Holt Lodge, Farnham, Surrey GU10 4LH, UK;

4. Department of Earth, Atmospheric, and Planetary Sciences, Purdue University, 550 Stadium Mell Drive, West Lafayette, Indiana 47907, USA;

5. NERC Isotope Geosciences Laboratory, British Geological Survey, Keyworth, Nottingham NG12 5GG, $U K$

6. ICREA at CREAF, Cerdanyola del Valles, 08023 Barcelona Spain

*Corresponding author: R. Guerrieri

University of New Hampshire

Earth Systems Research Center,

Morse Hall, 8 College Rd

Durham, NH 03824, USA

rossellaguerrieri@gmail.com 


\section{Abstract}

2 This study examines the role of tree canopies in processing atmospheric nitrogen $\left(N_{d e p}\right)$ for

3 four forests in the UK subjected to different $N_{\text {dep }}$ loads: Scots pine and beech stands under

4 high $N_{\text {dep }}\left(\mathrm{HN}, 13\right.$ and $19 \mathrm{~kg} \mathrm{~N} \mathrm{ha}^{-1} \mathrm{yr}^{-1}$, respectively), compared to Scots pine and beech

5 stands under low $N_{\text {dep }}\left(\mathrm{LN}, 9 \mathrm{~kg} \mathrm{~N} \mathrm{ha}{ }^{-1} \mathrm{yr}^{-1}\right)$. Changes of $\mathrm{NO}_{3}-\mathrm{N}$ and $\mathrm{NH}_{4}-\mathrm{N}$ concentrations in

6 rainfall $(\mathrm{RF})$ and throughfall $(\mathrm{TF})$ together with a quadruple isotope approach, which

7 combines $\delta^{18} \mathrm{O}, \Delta^{17} \mathrm{O}$ and $\delta^{15} \mathrm{~N}$ in $\mathrm{NO}_{3}{ }^{-}$and $\delta^{15} \mathrm{~N}$ in $\mathrm{NH}_{4}{ }^{+}$, were used to assess $\mathrm{N}$

8 transformations within the canopies. Generally, $\mathrm{HN}$ sites showed higher $\mathrm{NH}_{4}-\mathrm{N}$ and $\mathrm{NO}_{3}-\mathrm{N}$

9 concentrations in RF compared to the $\mathrm{LN}$ sites. Similar values of $\delta^{15} \mathrm{~N}_{-} \mathrm{NO}_{3}{ }^{-}$and $\delta^{18} \mathrm{O}$ in RF

10 suggested similar source of atmospheric $\mathrm{NO}_{3}{ }^{-}$(e.g., local traffic), while more positive values

11 for $\delta^{15} \mathrm{~N}^{-\mathrm{NH}_{4}}{ }^{+}$at $\mathrm{HN}$ compared to LN likely reflected the contribution of dry $N_{\text {dep }}$ from

12 intensive local farming. The isotopic signatures of the $\mathrm{N}$-forms changed during canopy

13 processing, although changes in ion concentrations between RF and TF were significant only

14 at the $\mathrm{HN}$ sites. ${ }^{15} \mathrm{~N}$-enriched $\mathrm{NH}_{4}{ }^{+}$in $\mathrm{TF}$ compared to $\mathrm{RF}$ at all sites suggested canopies

15 played an important role in buffering dry $N_{\text {dep }}$ also at the low atmospheric $\mathrm{N}$ load. By using

$16 \Delta^{17} \mathrm{O}$, we could prove for the first time that up to $60 \%$ of $\mathrm{NO}_{3}^{-}$in $\mathrm{TF}$ at the $\mathrm{HN}$ sites derived

17 from nitrification occurring in tree canopies, with a higher fraction in beech vs. Scots pine.

18 Our study suggests that tree canopies do not play a passive role in the $\mathrm{N}$ cycling within forest

19 ecosystems. Processing of $N_{d e p}$ within canopies should not be neglected and needs further

20 exploration, with the combination of powerful tracers, i.e., $\Delta^{17} \mathrm{O}$, in order to better quantify the 21 role of forests as sinks but also sources of $\mathrm{N}$.

24 Key words: Nitrogen deposition, $\delta^{15} \mathrm{~N}, \delta^{18} \mathrm{O}, \Delta^{17} \mathrm{O}, \mathrm{NH}, \mathrm{NO} \mathrm{O}_{3}$, forest canopy interception, 25 canopy nitrification, Scots pine, beech 


\section{Introduction}

3 Forest canopies play a significant role in regulating carbon and water exchanges with the 4 atmosphere, with profound effects on climate. On one hand, through photosynthesis in the 5 canopy, forests remove from the atmosphere approximately $30 \%$ of anthropogenically 6 produced carbon dioxide $\left(\mathrm{CO}_{2}\right)$ annually (Schulze, 2006; Canadell et al., 2007), thus 7 contributing to the mitigation of climate change. On the other hand, $\mathrm{CO}_{2}$ uptake occurs at the 8 expense of water taken up from the soil and subsequently lost through stomata during 9 transpiration, with both having significant effects on the terrestrial hydrological cycle (Bonan, 10 2008).

11 The contribution of tree canopies in altering the chemical composition of precipitation and, 12 consequently, the nutrient cycling within a forest has been less investigated. In particular, it is 13 unclear whether the deposition of reactive nitrogen species $\left(N_{\mathrm{dep}}\right)$ to canopies is retained, re14 emitted and/or altered by chemical or biological reactions, and what a portion and chemical 15 form of deposited $\mathrm{N}$ eventually reaches the soil as washed out $\mathrm{N}$-compounds. Interception of $16 N_{\text {dep }}$ by forest canopies contributes to the cycling of $\mathrm{N}$ in the terrestrial biosphere, thereby 17 affecting plant health, community structure and biodiversity, nutrient cycling, greenhouse gas 18 balance, soil pH and water quality (Cape and Pearcy, 1998; Galloway et al., 2004; Lindberg et 19 al., 1986; Pitcairn et al. 1998; Pitman et al., 2010; Prescott, 2002; Rennenberg and Gessler, 20 1999; Vanguelova et al., 2011; Vitousek et al,. 1997).

21 Understanding all the interactions taking place between atmospheric $\mathrm{N}$ and forest canopies, 22 under different environmental conditions, for various forest types (e.g., conifer vs. broadleaf 23 forests), for contrasting $\mathrm{N}$ loadings, chemical forms and species remains complex. Systematic 24 monitoring of the main $\mathrm{N}$ chemical species (i.e., $\mathrm{NH}_{4}{ }^{+}, \mathrm{NO}_{3}{ }^{-}$, dissolved organic $\mathrm{N}$ ) in rainfall 25 (RF) and throughfall (TF) has now been carried out for almost two decades in a network of 
1 experimental European forests (i.e., Level II network of ICP plots http://icp-forests.net/).

2 While these measurements quantify the atmospheric $\mathrm{N}$ inputs to forests and soils, they have

3 not been useful for assessing in-canopy processes that may be affecting changes in $\mathrm{N}$

4 compounds.

$5 \quad$ Forests are particularly efficient at scavenging pollutants via dry and occult deposition due to

6 their aerodynamically rough canopies (Fowler et al. 1989). As a consequence, the total $\mathrm{N}$

7 speciation and $\mathrm{N}$ concentration in $\mathrm{RF}$ differ from those in TF. Fluxes of $\mathrm{N}$ in TF reflect a

8 mixture of wet, occult (fog/cloud), and dry deposition, that may also be chemically or

9 biologically modified during canopy exchange and uptake. Commonly, TF has a higher N-

10 compounds concentration compared with RF, particularly in area subjected to high $\mathrm{N}$ input

11 from the atmosphere (Vanguelova et al., 2010), due to the washing out of dry $N_{d e p}$ through

12 forest canopies. Occult deposition can also be marked in areas where seasonal fogs and $\mathrm{N}$

13 pollution sources coincide. This has resulted in very large $\mathrm{N}$ inputs $\left(25-45 \mathrm{~kg} \mathrm{ha}^{-1} \mathrm{yr}^{-1}\right)$ to the

14 most highly exposed forests of the Los Angeles air basin (Bytnerowicz and Fenn, 1996).

15 Foliar uptake of aqueous $\mathrm{N}$ was recently proved to occur in beech and birch, with $\mathrm{NH}_{4}{ }^{+}$more

16 readily taken up than the $\mathrm{NO}_{3}^{-}$(Wuyts et al., 2015). Ammonia is readily absorbed directly

17 onto foliage and TF $\mathrm{N}$ fluxes are enhanced in forests that are near $\mathrm{NH}_{3}$ sources such as

18 agricultural areas (Vanguelova and Pitman, 2009). Moreover, in very low $N_{d e p}$ areas (e.g.,

19 total $N_{\text {dep }}$ of 2-3 $\mathrm{kg} \mathrm{ha}^{-1} \mathrm{yr}^{-1}$ ), such as in Finland, tree canopies tend to retain much of the $\mathrm{N}$

20 they capture by dry deposition due to uptake by epiphytic lichens, microbial immobilization

21 within the canopy, $\mathrm{N}$ absorption into foliage and assimilation by leaves and stems (Mustajärvi

22 et al., 2008). A recent study conducted in forests within the Italian national long-term

23 monitoring network CONECOFOR reported a canopy consumption of $\mathrm{N}$ for sites at low $N_{\text {dep }}$,

24 i.e., $<4-6 \mathrm{~kg} \mathrm{~N} \mathrm{ha}^{-1} \mathrm{yr}^{-1}$ (Ferretti et al., 2014). Similarly, in a study conducted in three

25 National Park in Washington State (USA) subjected to low $N_{d e p}$ was found that up to $90 \%$ of 
1 the atmospheric $\mathrm{N}$, mostly in the form of $\mathrm{NO}_{3}-\mathrm{N}$, was consumed by the forest canopies (Fenn 2 et al., 2013).

3 The stable nitrogen isotope composition $\left(\delta^{15} \mathrm{~N}\right)$ of wet $N_{\text {dep }}$ has helped to characterize the 4 sources of atmospheric N (Freyer, 1991; Heaton, 1987, Kendall et al. 2007 and references 5 therein) and its transformations when interacting with the biosphere, as assessed through 6 measurements of $\delta^{15} \mathrm{~N}$ in plants and soil (Ammann et al., 1999; Guerrieri et al., 2009, 2011;

7 Nadelhoffer et al., 1999; Saurer et al., 2004; Savard et al., 2009). In addition, observations

8 have been made of changes in the $\delta^{15} \mathrm{~N}$ of $\mathrm{NO}_{3}{ }^{-}$in TF that suggested the occurrence of 9 nitrification processes in the canopy (i.e., from $\mathrm{NH}_{4}{ }^{+}$to $\mathrm{NO}_{3}{ }^{-}$) of Norway spruce of central 10 Europe (Sah and Brumme, 2003) and of montane rain forest in Ecuador (Schwarz et al., 11 2011). Teuber et al. (2007) found evidence that autotrophic nitrifiers were present in the 12 needles of a spruce forest exposed to high levels of $N_{\text {dep }}$ (but not in needles of tree canopies 13 exposed to low levels of $N_{\text {dep }}$ ), and proposed that canopy $\mathrm{N}$ transformations may partly be 14 bacterial. However, a broad range of processes can lead to similar alterations of TF isotopic 15 composition, so distinguishing between various processes using a single-isotope approach is 16 challenging.

17 The application of the dual isotope approach, i.e., the combined measurement of $\delta^{15} \mathrm{~N}$ and $18 \delta^{18} \mathrm{O}$ in $\mathrm{NO}_{3}{ }^{-}$in bulk precipitation and stream water has provided another important step 19 towards a better understanding of the importance of $N_{\text {dep }}$ and of its cycling in forests. For 20 example, $\delta^{18} \mathrm{O}$ can help assess whether the $\mathrm{NO}_{3}{ }^{-}$in the soil solution derives from atmospheric $21 \mathrm{~N}$ or from nitrification processes. This is possible because of the large difference between the 22 isotopic signature of the atmospherically-derived $\mathrm{NO}_{3}{ }^{-}$(between 20 and $80 \%$ ) and the 23 signature for the $\mathrm{NO}_{3}{ }^{-}$derived from nitrification (between -10 and $+10 \%$, Kendall, 1998; 24 Burns and Kendall, 2002). 
1 An even more powerful approach has been proposed by Michalski et al. $(2002,2003)$ and

2 Costa et al., (2011) based on the measurements of $\delta^{17} \mathrm{O}$, together with $\delta^{18} \mathrm{O}$, to characterize

3 the sources of $\mathrm{NO}_{3}{ }^{-}$. Mass-dependent isotope fractionation leads to a consistent relationship

4 between $\delta^{17} \mathrm{O}$ and $\delta^{18} \mathrm{O}$, i.e.: $\delta^{17} \mathrm{O} \approx 0.52 \times \delta^{18} \mathrm{O}$ (Matsuhisa et al., 1978; Miller, 2002; Young

5 et al., 2002). However, in the case of ozone-mediated nitrate formation in the atmosphere,

6 mass-independent oxygen isotope compositions are observed (Michalski et al., 2002). This

7 'excess' of ${ }^{17} \mathrm{O}$ is quantified by $\Delta^{17} \mathrm{O}=\delta^{17} \mathrm{O}-0.52 \times \delta^{18} \mathrm{O}$ ). This means that ozone-derived

$8 \mathrm{NO}_{3}{ }^{-}$has a $\Delta^{17} \mathrm{O}>0$, while mass-dependent nitrification produces $\mathrm{NO}_{3}{ }^{-}$with $\Delta^{17} \mathrm{O}=0$. These

9 new tools offer the possibility to test some of the hypotheses previously proposed in the

10 literature, in particular to determine the relative contribution of occult dry deposition and of

11 bacterial-mediated nitrification in tree canopies to the chemical composition of canopy $\mathrm{TF}$

12 and the $\mathrm{N}$ input to the soil.

13 This study investigated whether $\mathrm{N}$ transformations occurred within the tree canopies of four

14 different forests in the UK subjected to different levels of $N_{\text {dep. }}$. The $\mathrm{NO}_{3}-\mathrm{N}$ and $\mathrm{NH}_{4}-\mathrm{N}$

15 concentrations in RF and TF were used to assess the role of canopy in filtering and changing

16 atmospheric $\mathrm{N}$ speciation. Furthermore, we used $\delta^{15} \mathrm{~N}-\delta^{18} \mathrm{O}$ and $\Delta^{17} \mathrm{O}$ in $\mathrm{NO}_{3}{ }^{-}$and the measure

17 of $\delta^{15} \mathrm{~N}_{\text {in }} \mathrm{NH}_{4}^{+}$, to assess if and how atmospheric $\mathrm{N}$ is processed within the canopy. In

18 particular we tested the following hypotheses: 1) In forests with low levels of $N_{\text {dep }}($ i.e., $10 \mathrm{~kg}$

$19 \mathrm{ha}^{-1} \mathrm{yr}^{-1}$ ) no differences exist between $\mathrm{RF}$ and $\mathrm{TF}$ for either ions concentrations or their

20 isotopic signature. Therefore, the composition and isotopic signatures of $\mathrm{NO}_{3}{ }^{-}$and $\mathrm{NH}_{4}{ }^{+}$in TF

21 should reflect that of atmospheric $\mathrm{N}$ in $\mathrm{RF}$, as a result of low canopy processing and canopy

22 uptake. 2) At high $N_{d e p}$ sites, exceeding critical $\mathrm{N}$ loads (i.e., 20-30 $\mathrm{kg} \mathrm{ha}^{-1} \mathrm{yr}^{-1}$ ), significant

23 differences exist between $\mathrm{RF}$ and $\mathrm{TF}$ for both ionic concentrations and their isotopic

24 signature, as a result of isotope fractionations during $\mathrm{N}$ processing within the canopy and

25 enhanced by the high input of wet and dry $N_{d e p}$. Finally, we used $\Delta^{17} \mathrm{O}$ to determine if a mass- 
1 dependent bacterial nitrification from $\mathrm{NH}_{4}{ }^{+}$to $\mathrm{NO}_{3}{ }^{-}$occurs in forest canopies at high $N_{\text {dep }}$

2 levels.

3

4

\section{Materials and Methods}

5

6

\subsection{Site description and sampling}

Two Scots pine (Pinus sylvestris L) stands and two beech (Fagus sylvatica L.) stands were studied. The pine stands were within the UK Forest Monitoring network (http://www.forestry.gov.uk/fr/INFD-67MEVC; Vanguelova et al., 2010), which is part of the

ICP European Forest Network. The two beech stands are part of long term experiments on monitoring of the effects of $N_{\text {dep }}$ on forest and soil biochemical cycling in the UK (Vanguelova and Pitman, 2009, 2011). Two sites, one for each tree species, were situated at Alice Holt and Rogate (6 km apart) in South East England and the remaining two sites were at Thetford ( $<8 \mathrm{~km}$ apart), East England. These sites were chosen on the basis of similarity in stand (age, density, and management history), climate, and soil conditions, but at contrasting levels of ambient $N_{d e p}$ (Table 1). In particular, the pine and beech stands at Thetford are subjected to higher background levels of $N_{\text {dep }}\left(13 \mathrm{~kg} \mathrm{~N} \mathrm{ha}^{-1} \mathrm{yr}^{-1}\right.$ and $19 \mathrm{~kg} \mathrm{~N} \mathrm{ha}^{-1} \mathrm{yr}^{-1}$, respectively) compared to forest stands at Alice Holt and Rogate (9-10 $\left.\mathrm{kg} \mathrm{N} \mathrm{ha}^{-1} \mathrm{yr}^{-1}\right)$ (Table1). Thetford in East Anglia, is known to be among the areas with highest atmospheric $\mathrm{N}$ inputs in the UK (RoTAP report, 2012; Vanguelova et al., 2010), mostly as dry $N_{\text {dep }}$, coming mainly from the intensive livestock farms (in particular pigs and chickens). Therefore, the two forest stands in Thetford will be referred to as HN (high nitrogen) and the forests in Rogate and Alice Holt as LN (low nitrogen) sites. Rainfall (RF) and throughfall (TF) sampling and analysis have been carried at the sites over a number of years by means of two bulk RF collectors and 10 TF collectors per site. Sampling and analytical procedures followed the level II protocols described in detail in the ICP Forests manual (2010). In this study only 
1 samples collected during the 2011 growing season, from June until November, were

2 considered.

3

$4 \quad 2.2$ Chemical and isotope analyses of water samples

5 After collection, $\mathrm{RF}$ and $\mathrm{TF}$ water samples were filtered through a $0.45 \mu \mathrm{m}$ membrane filter

6 and then analysed for $\mathrm{NH}_{4}-\mathrm{N}$, colorimetrically, for dissolved organic carbon (DOC) and total

$7 \mathrm{~N}$ by Carbon analyser (Shimadzu 5000, Osaka, Japan) and for $\mathrm{NO}_{3}-\mathrm{N}$ by Ion Chromatography

8 (Dionex DX-500). Dissolved organic nitrogen (DON) was calculated from measured total and

9 inorganic nitrogen forms. Other chemical components were measured as described in

10 Vanguelova et al. (2010), but were not included in this investigation. The RF and TF

11 elemental fluxes were calculated using measured water volumes at the sites and measured

12 elemental concentrations. Dry $N_{\text {dep }}$ values were estimated as difference between RF and TF

13 for each of the $\mathrm{N}$-form according to European ICP forest monitoring manual, which assumed

14 zero canopy exchange (ICP, 2010) (Table 1).

15 A sub-sample of the water analysed for ion concentrations was used for stable isotope 16 measurements. Water collected from June until August and then from September until

17 November was combined to obtain a minimum of $0.5 \mathrm{mg}$ of $\mathrm{NH}_{4}-\mathrm{N}$ and $\mathrm{NO}_{3}-\mathrm{N}$ for the 18 isotope analyses. This was also necessary for RF water samples collected at the two LN and 19 the two HN sites. Pooling RF water samples within each level of $N_{\text {dep }}$ are not likely to have 20 impacted the results. There was no significant differences in the amount of $\mathrm{NO}_{3}-\mathrm{N}^{-}$and $\mathrm{NH}_{4-}$ $21 \mathrm{~N}$ in $\mathrm{RF}$ at either of the two sites, except at Thetford where the $\mathrm{NH}_{4}-\mathrm{N}$ was significantly $22(p<0.05)$ higher in the beech relative to the pine stand. This was likely the result of the beech 23 site being located only a few hundred meters away from a chicken farm that generates $\mathrm{NH}_{3}$ 24 concentrations as high as $\sim 73 \mu \mathrm{g} / \mathrm{m}^{3}$ (Vanguelova and Pitman, 2009, 2011). 
1 Each RF and TF sample was composited as described above and then passed through cation

2 and anion exchange resins. Ammonium from the cation resin was eluted with hydrochloric

3 acid and converted to ammonium sulfate on a quartz filter paper using an alkaline diffusion

4 method (Heaton, 2001). Nitrate from the anion resin was eluted with hydrobromic acid, and

5 processed to silver nitrate (Chang et al., 1999; Heaton et al., 2004). The ${ }^{15} \mathrm{~N} /{ }^{14} \mathrm{~N}$ ratios of the

6 ammonium sulfate and the silver nitrate were analysed by combustion in a Flash EA on-line

7 to a Delta Plus XL mass spectrometer (ThermoFinnigan, Bremen, Germany), with $\cdot{ }^{15} \mathrm{~N}$

8 values versus air (atmospheric $\mathrm{N}_{2}$ ) calculated by comparison with standards calibrated against

9 IAEA N 1 and N 2 assuming these had values of $+0.4 \%$ and $+20.3 \%$ o, respectively. ${ }^{18} \mathrm{O} /{ }^{16} \mathrm{O}$

10 ratios of the silver nitrate were analysed by thermal conversion to $\mathrm{CO}$ gas at $1400^{\circ} \mathrm{C}$ in a TC-

11 EA on-line to a Delta Plus XL mass spectrometer (ThermoFinnigan, Bremen, Germany), with

$12 \delta^{18} \mathrm{O}$ values calculated versus SMOW by comparison with $\mathrm{IAEA}^{-\mathrm{NO}_{3}}$ assuming it had a value

13 of $+25.6 \%$ o. Analytical precisions ( $1 \mathrm{SD}$ ) were typically $<0.3 \%$ for $\cdot{ }^{15} \mathrm{~N}$ and $<0.6 \%$ o for

$14 \delta^{18} \mathrm{O}$. Finally, a sub-sample of the composite RF and TF water as described above was used

15 for $\delta^{17} \mathrm{O}$ measurements by Delta $\mathrm{V}$ Plus ratio mass spectrometer. $\mathrm{The}^{\mathrm{NO}_{3}}{ }^{-}$was converted to

$16 \mathrm{O}_{2}$ and $\mathrm{N}_{2}$ using the denitrifier method (Casciotti et al., 2002; Kaiser et al., 2009). Analytical

17 precisions (1 SD) for $\Delta^{17} \mathrm{O}$ were $<1.0 \%$ o based on replicate analysis of the reference material 18 USGS35.

\subsection{Data analyses}

$21 \quad$ 2.3.1 Statistical analyses

22 Concentrations of $\mathrm{NH}_{4}-\mathrm{N}, \mathrm{NO}_{3}-\mathrm{N}$ were log-transformed to account for non-normality and 23 variance heterogeneity, as assessed through Shapiro and Levene test, respectively. 24 Independent sample $t$-tests were employed to test for differences between deposition levels 25 (e.g. $\mathrm{HN}$ and $\mathrm{LN}$ ) and water samples (i.e., $\mathrm{RF}$ and $\mathrm{TF}$ ) for $\mathrm{NH}_{4}-\mathrm{N}$ and $\mathrm{NO}_{3}-\mathrm{N}$, while, within 
1 each water sample, differences between concentrations of different compounds were tested

2 through paired-samples $t$-test $(t)$. The non-parametric Wilcoxon test $(W)$ was employed when

3 log-transformed data did not conform to a normal distribution. Given the small sample size

4 available for the isotopic data, we calculated the difference in isotopic fractionation between

$5 \mathrm{TF}$ and RF without separating beech and pine stands and used a $t$-test to test the significance

6 of the difference between LN and HN stands. The level of significance of all statistical tests

7 was set as $p \leq 0.05$. R project statistical computing (vers. 3.0.2; R Core Development Team,

8 2014) was used for all the analyses.

9

\subsubsection{Mass balance calculation}

11 A mass balance approach, based on the use of $\Delta^{17} \mathrm{O}$, was employed to assess the sources of

$12 \mathrm{NO}_{3}{ }^{-}$collected in the TF at the $\mathrm{HN}$ sites by using end-members analyses using the following

13 equations:

$14 \quad \Delta^{17} O_{T f}=f_{B i o}\left(\Delta^{17} O_{B i o}\right)+f_{A t m}\left(\Delta^{17} O_{A t m}\right)$

15 where $\Delta^{17} \mathrm{O}_{T f}$ is the measured isotopic composition of $\mathrm{NO}_{3}{ }^{-}$in $\mathrm{TF}$, while $\Delta^{17} \mathrm{O}_{\text {Bio }}$ and $\Delta^{17} \mathrm{O}_{A t m}$ 16 indicate the isotopic signatures of the biologically and atmospherically-derived $\mathrm{NO}_{3}{ }^{-}$, 17 respectively. $f_{\text {Bio }}$ and $f_{A t m}$ are the unknown $\mathrm{NO}_{3}{ }^{-}$mole fractions from the two different sources, 18 the sum of which is $1 . f_{\text {Atm }}$ included both wet $\left(f_{\text {wet }}\right)$ and the dry $\left(f_{d r y}\right) \mathrm{NO}_{3}{ }^{-}$deposition washed 19 out from the canopy and not retained and/or taken up by the canopies $\left(f_{U}\right)$, i.e., $f_{A t m}=f_{W e t}+f_{D r y^{-}}$ $20 f_{U}$. Assuming that $\Delta^{17} \mathrm{O}_{\mathrm{Bio}}=0$ (Michalski et al. 2003), equation 1 can be reduced to:

$21 f_{A t m}=\left(\Delta^{17} O_{T f} / \Delta^{17} O_{A t m}\right)$

22 and

$23 f_{\text {Bio }}=1-f_{\text {Atm }}$ 


\section{Results}

3

\subsection{Concentrations of $\mathrm{NH}_{4}-\mathrm{N}$ and $\mathrm{NO}_{3}-\mathrm{N}$ in $\mathrm{RF}$ and $\mathrm{TF}$}

4

The concentration of $\mathrm{N}$ compounds in $\mathrm{RF}$ and $\mathrm{TF}$ at the two sites were significantly different.

At the two LN sites the concentrations of ions in RF were not significantly different (Fig. 1) and the $\mathrm{RF}$ and $\mathrm{TF}$ had similar $\mathrm{NH}_{4}-\mathrm{N}$ and $\mathrm{NO}_{3}-\mathrm{N}$ concentrations, (Scots pine: $t=1.78,7.97$ and $p=0.11,0.56$, respectively; beech: $W=163,125$ and $p=0.73,0.48$, respectively). In contrast, at the $\mathrm{HN}$ sites, the $\mathrm{NH}_{4}-\mathrm{N}$ and $\mathrm{NO}_{3}-\mathrm{N}$ concentrations were significantly higher in

9 TF compared to RF, for both Scots pine $(t=6.42,6.26,4.45$, respectively; all $p<0.001)$ and beech $(W=265,250$, respectively; all $p<0.001)$ (Fig. 1). Ion concentrations in both RF and TF were significantly higher at the $\mathrm{HN}$ (Scots pine $-\mathrm{RF}$ : $\mathrm{NO}_{3}-\mathrm{N}=0.58 \pm 0.09, \mathrm{NH}_{4}-\mathrm{N}=0.72 \pm$

0.09; TF: $\mathrm{NO}_{3}-\mathrm{N}=3.04 \pm 0.69, \mathrm{NH}_{4}-\mathrm{N}=2.47 \pm 0.38 ;$ Beech $-\mathrm{RF}: \mathrm{NH}_{4}-\mathrm{N}=2.09 \pm 0.18 ; \mathrm{TF}:$ $\left.\mathrm{NO}_{3}-\mathrm{N}=1.53 \pm 0.17, \mathrm{NH}_{4}-\mathrm{N}=7.18 \pm 0.9\right)$ than $\mathrm{LN}$ sites (Scots pine $-\mathrm{RF}: \mathrm{NO}_{3}-\mathrm{N}=0.31 \pm 0.05$, $\mathrm{NH}_{4}-\mathrm{N}=0.27 \pm 0.03 ; \mathrm{TF}: \mathrm{NO}_{3}-\mathrm{N}=0.69 \pm 0.30, \mathrm{NH}_{4}-\mathrm{N}=0.66 \pm 0.21 ;$ Beech $-\mathrm{RF}: \mathrm{NH}_{4}-\mathrm{N}=$ $0.5 \pm 0.12 ; \mathrm{TF}: \mathrm{NO}_{3}{ }^{-}=0.60 \pm 0.06, \mathrm{NH}_{4}-\mathrm{N}=0.47 \pm 0.06$ ), with the exception of $\mathrm{RF}$ in the beech stands, which had similar $\mathrm{NO}_{3}-\mathrm{N}$ concentrations $(\mathrm{LN}=0.47 \pm 0.09 ; \mathrm{HN}=0.53 \pm 0.05)$.

The mean of total $\mathrm{N}$ fluxes based on measured rainfall and measured during the 6 months we considered in this study (i.e., June to November 2011) are reported in Table 2. TF-N fluxes were higher than RF fluxes at the $\mathrm{HN}$ sites, with particular reference to the $\mathrm{NH}_{4}{ }^{+}$at the beech site. By contrast, at the LN sites RF N-fluxes were higher than TF-N fluxes for both species (Table 2).

\subsection{Values of $\delta^{15} \mathrm{~N}-\mathrm{NH}_{4}$}

24 Values of $\delta^{15} \mathrm{~N}$ of $\mathrm{NH}_{4}$ in $\mathrm{RF}$ (Fig. $2 \mathrm{~A}$ ) ranged from positive at the $\mathrm{HN}$ site $(+1.49 \pm 3.5 \%$ ) to very negative at the $\mathrm{LN}$ site $(-9.14 \% \circ \pm 0.2)$. Due to the limited number of measurements (i.e., 
$1 \mathrm{n}=2$ per species and per water sample), statistical analyses of isotope data were performed per

2 level of $N_{\text {dep }}$, combining data for both tree species and focussing on the differences between

3 RF and TF. However, TF values measured separately for beech and Scots pine are presented

4 in Figure $2 \mathrm{~A}$, to show the species-specific changes in the isotope compositions in $\mathrm{N}$

5 compounds collected below the canopies. More positive values were measured for $\delta^{15} \mathrm{~N}-\mathrm{NH}_{4}$

6 in TF compared to RF at both $\mathrm{HN}(t=-2.85, p<0.05)$ and $\mathrm{LN}(t=-15.16, p<0.001)$ sites. The

$7 \quad$ TF-RF difference for $\delta^{15} \mathrm{~N}$ in $\mathrm{NH}_{4}$ was much higher $(t=-2.65, p<0.05)$ at the $\mathrm{LN}$ compared to

8 the HN site (Fig. 2B).

3.3 Values of $\delta^{15} \mathrm{~N}, \delta^{18} \mathrm{O}$ and $\Delta^{17} \mathrm{O}-\mathrm{NO}_{3}$

11 The $\delta^{15} \mathrm{~N}$ in $\mathrm{NO}_{3}{ }^{-}$of $\mathrm{RF}$ (Fig. 3A) showed similar negative values at the $\mathrm{HN}(-3.4 \% \circ \pm 1.4)$ and $\mathrm{LN}$ sites $(-2.8 \% \circ \pm 1.7)$. Albeit lower, the $\delta^{15} \mathrm{~N}_{-\mathrm{NO}_{3}}{ }^{-}$values in TF at the $\mathrm{HN}$ sites $(\mathrm{diff}=-$ $4.9 \%$ \pm 3.4$)$ were only slightly different $(t=-1.72, p=0.06)$ compared to the LN sites (diff=

$14+1.1 \% \circ \pm 0.54$ ) (Fig. 3D). Despite differences between $\mathrm{RF}$ and $\mathrm{TF}$ for $\delta^{15} \mathrm{~N}_{\text {in }} \mathrm{NO}_{3}{ }^{-}$not being 15 significant within each level of $N_{\text {dep }}$, it is worth mentioning that at the $\mathrm{HN}$ sites, $\delta^{15} \mathrm{~N}$ in $\mathrm{NO}_{3}{ }^{-}$ showed more negative values in TF than RF, especially for Scots pine (Figure 3A).

The $\delta^{18} \mathrm{O}$ in $\mathrm{NO}_{3}{ }^{-}$of RF showed similar values at the two different levels of $N_{\text {dep }}$, i.e., $\mathrm{LN}=$ $1863.9 \% \circ \pm 0.88 ; \mathrm{HN}=64.1 \% \circ \pm 3.2$ (Fig. 3B). Within each level of $N_{\text {dep }}, \delta^{18} \mathrm{O}$ values did not significantly differ between RF and TF. However, a significant contrast $(t=-2.34, p<0.05)$ was

20 found in the difference between the $\delta^{18} \mathrm{O}$ values of $\mathrm{NO}_{3}{ }^{-}$in $\mathrm{TF}$ compared with $\mathrm{RF}$ across 21 levels of $N_{\text {dep }}$ (Figure 3E), with more negative $\delta^{18} \mathrm{O}_{-} \mathrm{NO}_{3}{ }^{-}$values at $\mathrm{HN}$ than $\mathrm{LN}$ sites.

$22 \Delta \Delta^{17} \mathrm{O}$ values measured in RF at our sites ranged from $23.14( \pm 0.58) \%$ at the $\mathrm{LN}$ sites to 25.53 $23( \pm 0.76) \%$ at the $\mathrm{HN}$ sites. A significant difference was found in the $\Delta^{17} \mathrm{O}$ of $\mathrm{NO}_{3}{ }^{-}$in the TF 24 vs. RF at the HN sites ( $W=16, p<0.05)$, but not at the LN sites. Within individual species, it is 
1 worth pointing out that beech showed lower $\Delta^{17} \mathrm{O}$ values than Scots pine (Figure $3 \mathrm{C}$ ). When

2 we considered the difference between $\mathrm{RF}$ and $\mathrm{TF}, \Delta^{17} \mathrm{O}$ values in $\mathrm{NO}_{3}{ }^{-}$had lower values at the

3 HN sites $(t=-1.86, p=0.05)$ than LN sites (Fig. 3F).

4 Combined plots for the three isotopic species of $\mathrm{NO}_{3}{ }^{-}$at the Scots pine and beech sites are 5 given in Figure 4 as trajectories of change from RF to $\mathrm{TF}$ values, to emphasise the 6 consequences of canopy processing for the three tracers, with particular references to forests 7 at $\mathrm{HN}$ levels. For Scots pine (Fig. $4 \mathrm{~A}$ and B), only in the case of $\mathrm{HN}$ sites $\operatorname{did} \delta^{15} \mathrm{~N}, \delta^{18} \mathrm{O}$ and 8 to less extent $\Delta^{17} \mathrm{O}$ values in TF diverge from those measured in RF. For beech (Fig.4 C and 9 D), distinct changes in $\delta^{18} \mathrm{O}$ vs. $\delta^{15} \mathrm{~N}$ were not observed, and only in the case of HN sites, did $10 \quad \Delta^{17} \mathrm{O}$ become lower from RF to TF.

\subsection{Assessing the source of $\mathrm{NO}_{3}{ }^{-}$in the $\mathrm{TF}$ at the sites with high atmospheric $\mathrm{N}$ loads}

Mass balance calculations (Eq. 2 and 3 in the section 2.3.2) were used to estimate the relative contribution of atmospheric vs. nitrification-derived $\mathrm{NO}_{3}{ }^{-}$collected underneath tree canopies. Using the two end-member mixing model with $\Delta^{17} \mathrm{O}$ values measured in TF and RF during 2011 growing season (Table 3), the fraction of $\mathrm{NO}_{3}{ }^{-}$in $\mathrm{TF}$ coming from nitrification $\left(\mathrm{f}_{\text {bio }}\right)$ ranged from 0.13 up to 0.6 (i.e., 13 to $60 \%$ ) at the two $\mathrm{HN}$ sites (Fig. 5A). Most of the $\mathrm{NO}_{3}{ }^{-}$ collected in the TF at the Scots pine stand derived from the atmosphere (mean of $\mathrm{f}_{A t m}=$ $0.83 \pm 0.05$ ), with only a minor contribution from nitrification (mean of $\mathrm{f}_{B i o}=0.17 \pm 0.05$ ). By contrast, biologically-derived $\mathrm{NO}_{3}{ }^{-}$seemed to be the dominant fraction of the $\mathrm{NO}_{3}{ }^{-}$in $\mathrm{TF}$ of the beech stand $\left(\mathrm{f}_{B i o}=0.59 \pm 0.04\right)$, at least for the time period considered in this study (Fig. 5 A). Interestingly, the $\mathrm{f}_{B i o}$ seems to show a species specific seasonal trend, although the few point measurements did not allow us to test it statistically (Fig. 5B). Nevertheless, the mass balance calculations did not help assessing the source of $\mathrm{NO}_{3}{ }^{-}$in $\mathrm{TF}$ at the $\mathrm{LN}$ sites. When we used eq. 2 with $\Delta^{17} \mathrm{O}$ values measured at the $\mathrm{LN}$ sites, we obtained values of $\mathrm{f}_{A t m}>1$ for beech 
$1 \quad\left(\mathrm{f}_{\mathrm{Atm}}=1.1\right.$ in June-August and 1.2 in September-November $)$, which then held to negative

2 values for $f_{\text {Bio. }}$. Whereas in the case of the Scots pine $f_{A t m}$ was $>1$ (i.e., 1.2 ) for the late

3 summer/fall months, while in the most active period of the growing season we were able to

4 detect that $\mathrm{f}_{A t m}$ and $\mathrm{f}_{\text {Bio }}$ were 0.51 and 0.49 , respectively. However, the two end-member

5 mixing model with $\Delta^{17} \mathrm{O}$ should be used with caution at the $\mathrm{LN}$ sites. Indeed, in this case

6 using $\Delta^{17} \mathrm{O}$ as the end-member of the mixing model can be sensitive to errors, due to the low

$7 \quad \mathrm{NO}_{3}-\mathrm{N}$ concentrations in $\mathrm{RF}$ and similar $\mathrm{NO}_{3}-\mathrm{N}$ values in $\mathrm{RF}$ and TF coupled with the lack of

8 difference in $\Delta^{17} \mathrm{O}-\mathrm{NO}_{3}{ }^{-}$between $\mathrm{RF}$ and $\mathrm{TF}$.

9

\section{Discussion}

\subsection{Characterizing atmospheric $N$ and its isotopic signatures at the contrasting $N_{\text {dep }}$ levels}

Both tree species at $\mathrm{HN}$ sites were subjected to air masses with high $\mathrm{NH}_{3}$ concentrations and had higher $\mathrm{NH}_{4}-\mathrm{N}$ deposition relative to the $\mathrm{LN}$ sites. The $\mathrm{HN}$ beech site, which is right next to an intensive chicken farm, is trapping the farms high $\mathrm{NH}_{3}$ emissions along a very distinct $200 \mathrm{~m}$ long $\mathrm{N}$ gradient where concentrations decrease to levels similar to those in the Scots pine site or the unpolluted Alice Holt site (Vanguelova and Pitman, 2009). This is showed by the higher $\mathrm{NH}_{4}-\mathrm{N}$ concentrations at the beech site than the HN Scots pine site, while no difference was found for $\mathrm{NO}_{3}-\mathrm{N}$ concentrations (Fig. 1). These results are in line with the results from long-term monitoring within the ICP forest network, which showed that Thetford is among the sites receiving highest $\mathrm{N}$ deposition in the UK (RoTAP report, 2012;

Vanguelova et al., 2010), due to the high $N_{\text {dep }}$, mostly as dry $N_{\text {dep }}$ and in the reduced form, coming mainly from the intensive livestock farms (in particular pigs and chickens).

Most of the $\mathrm{N}$ deposited as $\mathrm{NO}_{3}-\mathrm{N}$ came from the wet portion and $\mathrm{NO}_{3}-\mathrm{N}$ deposition was similar at both $\mathrm{HN}$ and $\mathrm{LN}$ sites (e.g., 3.3 and $3.2 \mathrm{~kg} \mathrm{~N} \mathrm{ha}^{-1} \mathrm{yr}^{-1}$, respectively; Table 1). This 
1 supports the evidence that in the comparisons of HN with LN areas, amount and chemical

2 form of dry deposition play important roles in canopy $\mathrm{N}$ filtering and in the amount reaching

3 the soils. Records over more than 10 years also suggest the overall total $N_{d e p}$ at the Thetford

4 pine site has decreased due to reductions in wet (in both forms $\mathrm{NH}_{4}-\mathrm{N}$ and $\mathrm{NO}_{3}-\mathrm{N}$ ) rather than

5 dry deposition (Vanguelova et al., 2010), confirming the national trend (RoTAP, 2012). The

6 different contribution of dry $v s$. wet $N_{\text {dep }}$ at the site-level is in agreement with deposition rates

7 obtained from $5 \times 5 \mathrm{~km}$ scale modelled deposition map (RoTAP report, 2012). The modelled

$8(5 \times 5 \mathrm{~km})$ data suggested similar values of the total oxidized $\mathrm{N}$ forms $\left(\mathrm{NO}_{3}, \mathrm{NO}_{2}\right.$ and $\left.\mathrm{HNO}_{3}\right)$

9 between HN (17.92 $\left.\mathrm{kg} \mathrm{ha}^{-1} \mathrm{yr}^{-1}\right)$ and LN (18.68 17.92 $\left.\mathrm{kg} \mathrm{ha}^{-1} \mathrm{yr}^{-1}\right)$ sites. Whereas, the HN

10 and $\mathrm{LN}$ sites had different rates of measured $\mathrm{NH}_{3} / \mathrm{NH}_{4}$ deposition $\left(30 \mathrm{~kg} \mathrm{ha}^{-1} \mathrm{yr}^{-1}\right.$ and $16 \mathrm{~kg}$

$11 \mathrm{ha}^{-1} \mathrm{yr}^{-1}$, respectively) with the dry $\mathrm{NH}_{4} / \mathrm{NH}_{3}$ deposition contributing the most to the total

$12\left(\mathrm{HN}=25.5\right.$ versus $\left.\mathrm{LN}=11.31 \mathrm{~kg} \mathrm{ha}^{-1} \mathrm{yr}^{-1}\right)$. In contrast there were similar rates of $\mathrm{NH}_{4}{ }^{+}$wet

13 deposition at both the HN $\left(5.7 \mathrm{~kg} \mathrm{ha}^{-1} \mathrm{yr}^{-1}\right)$ and LN $\left(5.3 \mathrm{~kg} \mathrm{ha}^{-1} \mathrm{y}^{-1}\right)$ sites. This suggests that

14 capturing small scale variability in $N_{d e p}$, and especially as dry deposited $\mathrm{NH}_{3}$ is vital to

15 understanding and assessing the impact on the environment.

16 Isotopic signatures measured in $\mathrm{NO}_{3}{ }^{-}$and $\mathrm{NH}_{4}{ }^{+}$in $\mathrm{RF}$ (Fig. 2, 3A, B) at our sites were in the

17 same range of values found in previous analyses of monthly rainfall samples from a range of

18 sites in the UK (Heaton et al, 1997; Curtis et al., 2012; Heaton, unpublished data; Table 4).

19 Overall, $\delta^{15} \mathrm{~N}$ values in $\mathrm{NH}_{4}{ }^{+}$measured across the UK ranged from negative to positive values

$20(-12.6 \%$ o to $+2.8 \%$ ) , with a mean of $-4.3 \%$. The positive values observed at the Thetford sites

21 are likely reflecting the contribution of $\mathrm{NH}_{4} / \mathrm{NH}_{3}$ emissions coming from the chicken

22 intensive farms in the area. Indeed, Heaton et al. (1997) reported that the $\cdot{ }^{15} \mathrm{~N}$ value of TF

23 ammonium in part of a Scots pine plantation artificially fumigated with ammonia gas was

$2417 \%$ higher than the value for TF in the non-fumigated part of the plantation. Moreover, in a

25 recent study Yeatman et al. (2001) measured $\delta^{15} \mathrm{~N}$ values of $+13.5 \%$ o in aerosol- $\mathrm{NH}_{4}$ sampled 
1 near chicken, cow and pig livestock enterprises and positive $\delta^{15} \mathrm{~N}$ values in bulk precipitation

2 were also reported by Emmett et al. (1998) for two conifer stands near livestock feed lots in 3 the Netherland.

4 The $\delta^{15} \mathrm{~N}$ values of $\mathrm{NO}_{3}{ }^{-}$were in the same range as those reported in the study by Heaton et 5 al. (1997). However, a high range of values was measured across the UK $(-8.2 \%$ o to $+4.3 \%$ ) 6 (Table 4), with a mean $\delta^{15} \mathrm{~N}_{-} \mathrm{NO}_{3}$ values of $-2 \%$. A similar range of $\delta^{15} \mathrm{~N}$ values in $\mathrm{NO}_{3}{ }^{-}$from $7-11 \%$ to $+3.5 \%$ was reported in studies across the USA (Kendall et al., 1998; Kendall et al., 8 2007; Elliott et al., 2007), while Tobari et al. (2010) measured $\delta^{15} \mathrm{~N}$ values in bulk 9 precipitation ranging from -7 to $+15.4 \%$ across different watersheds in Japan. Moreover, a 10 number of studies in the literature used $\delta^{15} \mathrm{~N}$ to assess the anthropogenic $\mathrm{NO}_{\mathrm{x}}$ source. For 11 instance, very negative $\left(-13 \%\right.$ o to $-2 \%$ ) $\cdot{ }^{15} \mathrm{~N}-\mathrm{NO}_{\mathrm{x}}$ values were reported in the case of 12 emissions coming from traffic, while positive values (between $4 \%$ and $16 \%$ ) were measured 13 for emissions from coal-fired power plants (Heaton, 1990). Similar values of $\delta^{15} \mathrm{~N}_{-} \mathrm{NO}_{3}$ in RF 14 at $\mathrm{HN}$ and $\mathrm{LN}$ sites in our study suggest a similar anthropogenic $\mathrm{NO}_{\mathrm{x}}$ source, most likely 15 emissions coming from local road traffic. This is confirmed also by the similar values we 16 measured for $\delta^{18} \mathrm{O}-\mathrm{NO}_{3}$ in $\mathrm{RF}$, irrespective of the $N_{\text {dep }}$ levels (i.e., $\mathrm{LN}=63.9 \% 0 \pm 0.88$ and $17 \mathrm{HN}=64.1 \% \circ \pm 3.2$ ). Moreover, $\Delta{ }^{17} \mathrm{O}$ in $\mathrm{RF}$ at the $\mathrm{HN}$ sites was $2 \%$ higher than that measured 18 at the $\mathrm{LN}$ sites, suggesting that $\mathrm{NO}_{\mathrm{x}}$ went through different oxidation processes (Michlaski et 19 al., 2003). $\Delta^{17} \mathrm{O}$ values measured at our sites (ranging from $22 \%$ to $26 \%$ ) were similar to 20 those reported by Costa et al. (2011) for $\mathrm{NO}_{3}{ }^{-}$in rain samples $(23.1 \%$ 21 Michigan and by Michalski et al. (2004) in aerosol (26\%o \pm 3 ) sampled in Southern 22 California.

244.2 Canopy N processes as detected through stable isotopes 
1 Our analyses showed that only at $\mathrm{HN}$ sites there were significant increases in $\mathrm{NH}_{4}-\mathrm{N}$ and

$2 \mathrm{NO}_{3}-\mathrm{N}$ concentrations in TF relative to RF, irrespective of tree species (Fig. 1), confirmed

3 also when we looked at the $\mathrm{N}$ fluxes (Table 2). This result is in line with previous studies in

4 the literature (Vanguelova et al., 2010; De Vries et al., 2014) and it suggests that at areas with

5 high dry $N_{\text {dep }}$, canopy filtering and rain washing will contribute to increasing the $\mathrm{N}$ input to

6 the soils compared to low dry $N_{\text {dep }}$ areas. By contrast, at the LN sites, TF-N fluxes were lower

7 than RF $\mathrm{N}$-fluxes, suggesting that most of the atmospheric $\mathrm{N}$ is retained by tree canopies, as

8 observed also in other studies in the literature (Fenn et al., 2013, Ferretti et al., 2014).

9 However, is it only the contribution of dry $N_{d e p}$ that helps explaining the higher $\mathrm{NH}_{4}{ }^{+}$and

$10 \mathrm{NO}_{3}{ }^{-}$concentrations in $\mathrm{TF}$ at the $\mathrm{HN}$ sites? To answer to this question, we used a quadruple

11 isotope approach, namely the $\delta^{15} \mathrm{~N}^{\text {in }} \mathrm{NO}_{3}{ }^{-}$and $\mathrm{NH}_{4}{ }^{+}, \delta^{18} \mathrm{O}$ and $\Delta^{17} \mathrm{O}$ in $\mathrm{NO}_{3}{ }^{-}$.

12 The pathway through the canopies did affect the isotopic signature of both $\mathrm{NH}_{4}{ }^{+}$and $\mathrm{NO}_{3}{ }^{-}$,

13 with TF generally showing ${ }^{15} \mathrm{~N}$-enriched $\mathrm{NH}_{4}$ and ${ }^{15} \mathrm{~N}$-depleted $\mathrm{NO}_{3}{ }^{-}$.

14 The more positive values for $\delta^{15} \mathrm{~N}_{\text {in }} \mathrm{NH}_{4}{ }^{+}$collected in $\mathrm{TF}$ are consistent with the overall

15 increase of $\mathrm{NH}_{4}-\mathrm{N}$ in $\mathrm{TF}$ at the Thetford site (Fig. 1-2). In addition, the $\delta^{15} \mathrm{~N}$ values of $\mathrm{NH}_{4}^{+}$

16 in dry deposition tend to be higher than those measured in bulk precipitation (Heaton, 1997),

17 suggesting that a fraction of the measured TF originated from dry $N_{\text {dep }}$. The more positive

18 values $\delta^{15} \mathrm{~N}$ in $\mathrm{NH}_{4}-\mathrm{N}$ are also consistent with the occurrence of nitrification in the canopy,

19 which should result in the accumulation of ${ }^{15} \mathrm{~N}$-enriched $\mathrm{NH}_{4}{ }^{+}$(Högberg 1997), as a residual

20 product. Interestingly, while at the $\mathrm{LN}$ sites the $\mathrm{NH}_{4}-\mathrm{N}$ concentration did not vary

21 significantly from RF to TF, a fingerprint of dry $N_{d e p}$ was still detected at these sites by the

$22{ }^{15} \mathrm{~N}$ enrichment in $\mathrm{NH}_{4}{ }^{+}$underneath the canopies.

$23 \mathrm{NO}_{3}-\mathrm{N}$ concentrations in $\mathrm{TF}$ were higher at $\mathrm{HN}$ forest stands than at the $\mathrm{LN}$ stands, and it was

24 expected that this difference would be reflected also in the isotopic signature of both $\mathrm{N}$ and $\mathrm{O}$

25 in nitrate. The higher $\mathrm{NO}_{3}-\mathrm{N}$ at the $\mathrm{HN}$ sites for both Scots pine and beech in $\mathrm{TF}$, could in 
1 principle also result from a combination of dry deposition and canopy nitrification processes.

2 As in the case of $\mathrm{NH}_{4}{ }^{+}$, higher values of $\delta^{15} \mathrm{~N}$ of $\mathrm{NO}_{3}{ }^{-}$in TF compared to $\mathrm{RF}$ could be 3 expected (Heaton, 1997), but were not found at these sites (Fig. 3A). Nitrification of $\mathrm{NH}_{4}{ }^{+}$ 4 leads to the production of ${ }^{15} \mathrm{~N}$ depleted $\mathrm{NO}_{3}{ }^{-}$leaving behind more ${ }^{15} \mathrm{~N}$ enriched $\mathrm{NH}_{4}{ }^{+}$ 5 (Högberg, 1997). Indeed, we did measure more negative (but not significantly so) $\delta^{15} \mathrm{~N}^{-\mathrm{NO}_{3}}{ }^{-}$ 6 values in $\mathrm{TF}$ at the $\mathrm{HN}$ site (diff $=-4.9 \%$ \pm 3.4 ) compared to the $\mathrm{LN}$ (diff $=+1.1 \% \circ \pm 0.54$ ).

7 The ${ }^{15} \mathrm{~N}$ depletion of $\mathrm{NO}_{3}{ }^{-}$in $\mathrm{TF}$ was particularly detected for Scots pine at the $\mathrm{HN}$ site. (Fig.

$83 \mathrm{~A}, 4 \mathrm{~A}) \mathrm{A}$ decrease in $\delta^{15} \mathrm{~N}$ in $\mathrm{NO}_{3}{ }^{-}$from $\mathrm{RF}$ to $\mathrm{TF}$ was reported in studies in a spruce forest

9 in Germany by Sah and Brumme (2003) and in a montane rain forest in Ecuador by Schwarz

10 et al. (2011), explained in both cases by isotope fractionation during nitrification of $\mathrm{NH}_{4}{ }^{+}$to

$11 \mathrm{NO}_{3}{ }^{-}$in the canopy leaves. However, none of these previous studies could unequivocally

12 attribute the shifts in ${ }^{15} \mathrm{~N}_{-} \mathrm{NO}_{3}$ to biological $\mathrm{NH}_{4}{ }^{+}$nitrification. In our study, evidence of

13 nitrification occurring within the canopy was clearly provided by $\Delta^{17} \mathrm{O}$, since there is not

14 likely to be a big $\Delta^{17} \mathrm{O}$ difference in dry deposited $\mathrm{NO}_{3}{ }^{-}$compared to wet $\mathrm{NO}_{3}{ }^{-}$. Indeed, using

15 a mass balance approach, we found that at the $\mathrm{HN}$ sites nitrification can contribute up to $60 \%$

16 to the $\mathrm{NO}_{3}{ }^{-}$recovered underneath the tree canopies (Fig. 5A, B). Interestingly, for beech at the

$17 \mathrm{HN}$, the $\delta^{18} \mathrm{O}-\mathrm{NO}_{3}$ signals in TF $v s$. RF could not clearly provide an indication of nitrification,

18 while $\Delta^{17} \mathrm{O}$ proved that the fractional contribution of biologically-derived $\mathrm{NO}_{3}{ }^{-}$was as much

19 as that from the atmospherically-derived $\mathrm{NO}_{3}{ }^{-}$(Fig. 5A). Interestingly, the seasonal trend of

$20 \mathrm{f}_{\text {Bio }}$ goes in the opposite direction for the two investigated species. Indeed the beech showed a

21 reduction in $\mathrm{f}_{B i o}$ towards in the late summer/fall, likely associated to the phenology and 22 therefore the changes in the leaf physiology.

23 One could ask: is it so relevant to determine the sources of the $\mathrm{NO}_{3}{ }^{-}$reaching the soil?

24 Beyond the effect of canopy nitrification on potential $\mathrm{N}$ uptake by trees, the fact that canopies

25 can process some of the atmospheric $\mathrm{NH}_{\mathrm{x}}$ before even reaching the soil has important 
1 implications on the different biogeochemical processes occurring in the soil. In particular, the

2 proportion of $\mathrm{NH}_{\mathrm{x}} v s . \mathrm{NO}_{\mathrm{x}}$ exchanged by canopies will affect the role of soil as sink (through

3 ammonification and nitrification) vs. source (by denitrification) of $\mathrm{N}$.

4 The dramatic reduction of $\delta^{15} \mathrm{~N}$ and to less extent of $\delta^{18} \mathrm{O}-\mathrm{NO}_{3}$ in TF $v s$. RF for the Scots pine

5 at HN (Fig. 4A) could not be attributed solely to atmospheric dry deposition or canopy

6 exchange. This result suggests that also other processes might take place at this site. One

7 possibility might be that $\mathrm{NO}_{\mathrm{x}}$ emissions from the soil, likely related to denitrification

8 processes, react with tree canopies before reaching the atmosphere. A number of studies have

9 shown that part of the soil $\mathrm{NO}$ emission can be converted to $\mathrm{NO}_{2}$ by reacting with ozone,

10 which in turn can be either trapped in the stem space below the canopy or processed again

11 within the canopy (Rennenberg et al., 1998; Dorsey et al., 2004; Duyzer et al., 2004;

12 Neirynck et al., 2007). Among the level II plots in the UK, symptoms of $\mathrm{N}$ saturation have

13 been observed at Thetford, with high mean annual $\mathrm{NO}_{3}{ }^{-}$concentrations in soil solution at the

14 Scots pine stand of up to $40 \mathrm{mg} / \mathrm{l}$ (Vanguelova et al., 2009, 2011). A preliminary study also

15 suggested significantly higher soil respiration at the HN compared to LN pine sites, which

16 may imply that the $\mathrm{NO}_{\mathrm{x}}$ emission could be higher too (Vanguelova, personal communication).

17 Under these conditions, denitrification might take place at this site, although no direct

18 measurements are currently available to support this hypothesis. Such denitrification is likely

19 to produce $\mathrm{NO}$ and $\mathrm{NO}_{2}$ depleted in both ${ }^{15} \mathrm{~N}$ and ${ }^{18} \mathrm{O}$ relative to soil nitrate, with very low,

20 negative $\delta^{15} \mathrm{~N}$ and $\delta^{18} \mathrm{O}$ values ( $\mathrm{Li}$ and Wang, 2008; Felix and Elliot, 2014). Subsequent

21 reactions with ozone would increase $\delta^{18} \mathrm{O}$ and $\Delta^{17} \mathrm{O}$ values, but not $\delta^{15} \mathrm{~N}$. Thus, nitrate formed

22 by this mechanism might have $\delta^{18} \mathrm{O}$ and $\Delta^{17} \mathrm{O}$ values similar to atmospheric nitrate, but with

23 very low $\delta^{15} \mathrm{~N}$ values compared to RF.

\section{Conclusion}


1 To our knowledge, this is the first study that combined measurements of $\mathrm{NO}_{3}-\mathrm{N}$ and $\mathrm{NH}_{4}-\mathrm{N}$

2 fluxes together with their relative isotope signatures, i.e., $\delta^{15} \mathrm{~N}_{\text {in }} \mathrm{NO}_{3}{ }^{-}$and $\mathrm{NH}_{4}{ }^{+}$and $\delta^{18} \mathrm{O}$ and

$3 \Delta^{17} \mathrm{O}$ in $\mathrm{NO}_{3}{ }^{-}$to determine the role of canopy filtering of atmospherically-derived $N_{\text {dep. }}$

4 Specifically, changes in $\Delta^{17} \mathrm{O}$ in $\mathrm{NO}_{3}{ }^{-}$as $\mathrm{N}$ passes through forest canopies had not previously

5 been determined. Oxygen isotopes have been mostly considered at the watershed level, to

6 characterize the source of $\mathrm{NO}_{3}{ }^{-}$in the stream water, but have not previously been applied to

7 the investigation of the role of canopy in processing atmospheric N. Our results partially

8 confirm our initial hypotheses that:

9 1) At the $\mathrm{LN}$ sites, ion concentrations in $\mathrm{TF}$ and their respective isotopic signatures

10 reflected the input of atmospheric $\mathrm{N}$ as derived from RF. However, isotope data revealed

11 that even with a low atmospheric $\mathrm{N}$ load, canopies played an important role in

12 intercepting and retaining dry $N_{\text {dep }}$ (with particular reference to the reduced $\mathrm{N}$-form),

13 which represents an additional (but often overlooked) $\mathrm{N}$ source relative to wet $N_{\text {dep }}$ as

14 assessed through RF.

15 2) At the $\mathrm{HN}$ sites, the passing of atmospheric $\mathrm{N}$ through canopies affected both ion 16 concentrations and their isotopic signature. The occurrence of dry deposition probably 17 explains the higher $\mathrm{NH}_{4}{ }^{+}$concentrations and ${ }^{15} \mathrm{~N}$ enrichment in $\mathrm{NH}_{4}{ }^{+}$measured below the 18 canopy in TF water vs. RF. As for the higher $\mathrm{NO}_{3}{ }^{-}$in TF vs. RF, the isotopes $\delta^{15} \mathrm{~N}$ and $\delta^{18} \mathrm{O}$ could not provide clear indications of its origin, even though for Scots pine $\delta^{15} \mathrm{~N}$ $\mathrm{NO}_{3}{ }^{-}$provided some indications of biologically-derived $\mathrm{NO}_{3}{ }^{-}$. The unambiguous response came however from $\Delta \Delta^{17} \mathrm{O}$, which allowed to determine that a consistent fraction of the $\mathrm{NO}_{3}{ }^{-}$recovered underneath the canopies derived from biological nitrification, with an unexpected higher magnitude at the beech stand. Moreover, the very negative values of $24 \quad \delta^{15} \mathrm{~N}$ in $\mathrm{NO}_{3}-\mathrm{N}$ for Scots pine at the $\mathrm{N}$-saturated site, suggested that nitrate could derive 
1 also from soil $\mathrm{NO}_{\mathrm{x}}$ emissions being re-processed and deposited again in the canopy before

2 mixing in TF water.

3 This study is part of a broader project, aiming to look at the effect of ambient $N_{\text {dep }}$ on tree

4 growth, water-use efficiency and $\delta^{15} \mathrm{~N}$ in tree rings. Hence, the characterization of the short-

5 term $\mathrm{N}$ input from the atmosphere is a crucial step toward a better understanding of the long-

6 term effect of $N_{\text {dep }}$ to be assessed through stable isotopes in tree rings (Guerrieri et al., in

7 preparation).

8 We acknowledge that the conclusions of this study rely on a limited number of isotope

9 measurements at each site and a limited selection of forest stands, which did not allow

10 detailed investigations of the tree species-specific pattern of canopy $\mathrm{N}$ transformations.

11 However, the study identified canopy processing of atmospheric deposition (and especially

12 canopy biological nitrification) as a major process that should not be neglected and needs

13 further exploration, to better quantify the role of forests as sinks but also sources of $\mathrm{N}$. This

14 has important implications for policy-related emission abatement strategies, which aim to

15 manage forests and landscape not only for enhancing C-sequestration, but also for 16 atmospheric $\mathrm{N}$ capture.

\section{Acknowledgment}

19 R. G. acknowledges the follow-on travel funding (2013) from the British Academy and the 20 Royal Society, following the Newton International Fellowship Grant no. NF082365 (200921 2011) funded by the Royal Society, the British Academy and the Royal Academy of 22 Engineering. MM acknowledges funding from NERC project grant NE/G00725X/1 and 23 NERC project grant IP-1205-1110. Funding for this work was also provided by Forest 24 Research and acknowledgments goes to Forest Research technical team for sample collection 
1 and the research laboratory for carrying out all chemical analysis. Rona Pitman has provided

2 help with the research and with final edits of this paper.

3

4

\section{References}

6 Ammann M, Siegwolf RTW, Pichlmayer F, Suter M, Saurer M, Brunold C (1999). Estimating

7 the uptake of traffic-derived $\mathrm{NO}_{2}$ from ${ }^{15} \mathrm{~N}$ abundance in Norway spruce needles. Oecologia

$8 \quad 118(2): 124-131$.

9 Bonan GB. Forests and climate change: forcings, feedbacks, and the climate benefits of forests (2008). Science 320 (5882) : 1444-1449. DOI:10.1126/science.1155121.

Bytnerowicz A, Fenn ME (1996). Nitrogen deposition in California forests: a review.

12

Environmental Pollution 92:127-146.

Burns $\mathrm{AD}$ and Kendall C. Analysis of $\delta^{15} \mathrm{~N}$ and $\delta^{18} \mathrm{O}$ to differentiate $\mathrm{NO}_{3}^{-}$sources in runoff at two watersheds in the Catskill Mountains of New York (2002). Water Resources Research 38 (5): 1051.

Canadell JG, Le Quéré C, Raupach MR, Field CB, Buitenhuis ET, Ciais P,Conway TJ, Gillett NP, Houghton RA, Marland G (2007). Contributions to accelerating atmospheric $\mathrm{CO}_{2}$ growth from economic activity, carbon intensity, and efficiency of natural sinks, PNAS 104 (47): $18866-18870$.

Cape JN, Percy KE. Use of needle epicuticular wax chemical composition in the early diagnosis of Norway spruce (Picea abies (L.) Karst.) decline in Europe (1998). Chemosphere 36 (4-5): 895-900.

Casciotti KL, Sigman DM, Hastings MJ, Bohlke JK, Hilkert A (2002). Measurement of the oxygen isotopic composition of nitrate in seawater and freshwater using the denitrifier method, Anal. Chem.: 74, 4905-4912. 
1 Chang CCY, Langston J, Riggs M, Campbell DH, Silva SR Kendall C (1999). A method for

2 nitrate collection for $\delta^{15} \mathrm{~N}$ and $\delta^{18} \mathrm{O}$ analysis from waters with low nitrate concentrations.

3 Canadian Journal of Fisheries and Aquatic Science 56: 1856-1864.

4 Costa AW, Michalski G,Schauer AJ,Alexander B, Steig EJ, Shepson PB (2011). Analysis of

5 atmospheric inputs of nitrate to a temperate forest ecosystem from $\Delta^{17} \mathrm{O}$ isotope ratio

6 measurements. Geophysical Research Letters 38: L15805.

7 Curtis CJ, Heaton THE, Simpson GL, Evans CD, Shilland J, Turner S (2012). Dominance of

8 biologically produced nitrate in upland waters of Great Britain indicated by stable isotopes.

9 Biogeochemistry 111: 535-554. DOI 10.1007/s10533-011-9686-8.

10 Dorsey JR, Duyzer JH, Gallagher MW, Coe H, Pilegaard K, Weststrate JH, Jensen NO,

11 Walton S (2004). Oxidized nitrogen and ozone interaction with forests. I: Experimental

12 observations and analysis of exchange with Douglas fir. Q.J.R. Meteorol. Soc. 130: 1941131955.

14 Duyzer JH, DorseyJR, Gallagher MW, Pilegaard K, Walton S (2004). Oxidized nitrogen and 15 ozone interaction with forests. II: Multi-layer process-oriented modelling results and a 16 sensitivity study for Douglas fir. Q.J.R. Meteorol. Soc. 130: 1957-1971.

17 De Vries W, Dobbertin MH, Solberg S, van Dobben HF, Schaub M (2014). Impacts of acid 18 deposition, ozone exposure and weather conditions on forest ecosystems in Europe: an 19 overview. Plant Soil 380:1-45.

20 Elliott EM, Kendall C, Wankel SD, Burns DA, Boyer EW, Harlin K, Bain DJ, Butler AJ 21 (2007). Nitrogen isotopes as indicators of $\mathrm{NO}_{x}$ source contributions to atmospheric nitrate 22 deposition across the midwestern and Northeastern United States. Environment Science 23 Technology 41: 7661-7667. 
1 Emmett BA, Kjonaas OJ, Gundersen P, Koopmans C, Tietema A, Sleep D (1998). Natural

2 abundance of ${ }^{15} \mathrm{~N}$ in forests across a nitrogen deposition gradient. Forest Ecology and

3 Management 101: 9-18.

4 Felix JD and Elliott EM (2014). Isotopic composition of passively collected nitrogen dioxide

5 emissions: Vehicle, soil and livestock source signatures. Atmospheric Environment 92: 359-

6366.

7 Fenn ME, Ross CS, Schilling SL, Baccus WD, Larrabee MA, Lofgren RA (2013)

8 Atmospheric deposition of nitrogen and sulfur and preferential canopy consumption of nitrate

9 in forests of the Pacific Northwest, USA. Forest Ecology and Management 302: 240-253

10 Ferretti M, Marchetto A, Arisci S, Bussotti F, Calderisi M, Carnicelli S, Cecchini G, Fabbio

11 G, Bertini G, Matteucci G, De Cinti B, Salvati L, Pompei E (2014). On the tracks of Nitrogen

12 deposition effects on temperate forests at their Southern European range- an observational

13 study from Italy. Global change and biology 20: 3423-3438.

14 Fowler D, Cape JN, Unsworth MH, Mayer H, Crowther JM, Jarvis PJ,

15 Gardiner B, Shuttleworth WJ (1989). Deposition of atmospheric pollutants on forests.

16 Philosophical Transactions of the Royal Society B 324:247-265.

17 Freyer HD (1991). Seasonal variation of ${ }^{15} \mathrm{~N} /{ }^{14} \mathrm{~N}$ ratios in atmospheric nitrate species, Tellus,

18 Ser. B 43: 30- 44.

19 Galloway JN, Aber JD, Erisman JW, Seitzinger SP, Howarth RW, Cowling EB, Cosby BJ

20 (2004). The nitrogen cascade. BioSciences; 53(4): 341-356.

21 Guerrieri MR, Siegwolf RTW, Saurer M, Jäggi M, Cherubini P, Ripullone F, M Borghetti

22 (2009). Impact of different nitrogen emission sources on tree physiology as assessed by a

23 triple stable isotope approach. Atmospheric Environment 43:410-419. 
1 Guerrieri R, Mencuccini M, Sheppard LJ, Saurer M, Perks M, Levy P, Sutton MA, Borghetti

2 M, Grace J (2011). The legacy of enhanced N and S deposition as revealed by the combined

3 analysis of $\delta^{13} \mathrm{C}, \delta^{18} \mathrm{O}$ and $\delta^{15} \mathrm{~N}$ in tree rings. Global Change and Biology 17:1946-1962.

4 Heaton THE (1987). ${ }^{15} \mathrm{~N} /{ }^{14} \mathrm{~N}$ ratios of nitrate and ammonium in rain at Pretoria, South Africa.

$5 \quad$ Atmospheric Environment 21: 843-852.

6 Heaton THE (1990). ${ }^{15} \mathrm{~N} /{ }^{14} \mathrm{~N}$ ratios of $\mathrm{NO}_{\mathrm{x}}$ from vehicle engines and coal-fired power

$7 \quad$ stations. Tellus $42: 304 \pm 307$

8 Heaton THE, Spiro B, Madeline S, Robertson C (1997). Potential canopy influences on the

9 isotopic composition of nitrogen and sulphur in atmospheric deposition. Oecologia 109:60010607.

11 Heaton THE (2001). Procedure and notes on the 'diffusion' method for 15N/14N analysis of 12 nitrate and ammonium. NERC Isotope Geosciences Laboratory, Report NIGL 176, 5 pp.

13 Heaton THE, Wynn P, Tye A (2004). Low ${ }^{15} \mathrm{~N} /{ }^{14} \mathrm{~N}$ ratios for nitrate in snow in the High 14 Arctic $\left(79^{\circ} \mathrm{N}\right)$. Atmospheric Environment 38: 5611-5621.

15 Högberg P (1997). ${ }^{15} \mathrm{~N}$ natural abundance in soil-plant systems. New Phytologist 137: 17916203.

17 Kaiser J,Hastings MG, Houlton BZ, Röckmann T, Sigman DM (2007). Triple oxygen isotope

18 analysis of nitrate using the denitrifier method and thermal decomposition of N2O. Anal.

19 Chem. 79: 599-607, doi:10.1021/ac061022s.

20 Kendall C (1998). Tracing Nitrogen Sources and Cycling in Catchments, in Isotope Tracers in

21 Catchment Hydrology, edited by C. Kendall and J. J. McDonnell, Elsevier Science, 22 Amsterdam. p 519-576.

23 Kendall C, Elliott EM, Wankel SD (2007). Tracing anthropogenic inputs of nitrogen to 24 ecosystems. In: Michener R, Lajtha K, Eds. Stable isotopes in ecology and environmental 25 science. Boston: Blackwell Publishing, p 375-449. 
1 ICP Forests (2010). Sampling and Analysis of deposition. In: Manual on methods and criteria

2 for harmonized sampling, assessment, monitoring and analysis of the effects of air pollution

3 on forests. UNECE, ICP Forests, ISBN: 978-926301-03-1. [http://www.icp-

4 forests.org/Manual.htm].

5 Li D and Wang X (2008). Nitrogen isotopic signature of soil-released nitric oxide (NO) after

6 fertilizer application. Atmospheric Environment 42: 4747-4754.

7 Lindberg SE, Lovett GM, Richter DD, Johnson DW (1986). Atmospheric Deposition and

8 Canopy Interactions of Major Ions in a Forest. Science 231 (4734): 141-145.

9 Matsuhisa Y, Goldsmith JR, Clayton RN (1978). Mechanisms of hydrothermal crystallization

10 of quartz at $250^{\circ} \mathrm{C}$ and $15 \mathrm{kbar}$, Geochimica Cosmochimica Acta 42(2): 173-182.

11 Michalski G, SavarinoJ, Böhlke JK, Thiemens M (2002). Determination of the total oxygen

12 isotopic composition of citrate and the Calibration of a $\Delta^{17} \mathrm{O}$ nitrate reference material.

13 Analytical Chemistry 74: 4989-4993.

14 Michalski G, Scott Z, Kabiling M, Thiemens MH (2003). First measurements and modeling

15 of $\Delta^{17} \mathrm{O}$ in atmospheric nitrate. Geophysical Research Letters 30 (16) 1870, doi:

$16 \quad 10.1029 / 2003$ GL017015.

17 Michalski G, Böhlke JK, Thiemens MH (2004). Long term atmospheric deposition as the

18 source of nitrates and other salts in the Atacama desert, Chile: New evidence from

19 mass-independent oxygen isotopic compositions, Geochim. Cosmochim. Acta 68(20): 4023-

20 4038, doi:10.1016/j.gca.2004.04.009.

21 Miller M F (2002). Isotopic fractionation and the quantification of O-17 anomalies in the 22 oxygen three-isotope system: an appraisal and geochemical significance, Geochimica 23 Cosmochimica Acta 66(11): 1881-1889.

24 Mustajärvi K, Merilä P, Derome J, Lindroos A-J, Helmisaari H-S, Nöjd P, Ukonmaaho L 25 (2008). Fluxes of dissolved organic and inorganic nitrogen in relation to stand characteristics 
1 and latitude in Scots pine and Norway spruce stands in Finland. Boreal Environ Res 13(suppl

$2 \quad$ B): 3-21.

3 Nadelhoffer KJ, Bridget AE, P Gundersen, OJ Kjùnaas, CJ Koopmansk, P Schleppi, A

4 Tietemak, RF Wright (1999). Nitrogen deposition makes a minor contribution to carbon

5 sequestration in temperate forests, Nature 398: 145- 148.

6 Neirynck J, Kowalski AS, Carrara A, Genouw G, Berghmans P, Ceulemans R (2007). Fluxes

7 of oxidised and reduced nitrogen above a mixed coniferous forest exposed to various nitrogen

8 emission sources. Environmental Pollution 149: 31-43.

9 Pitcairn CER, Leith ID, Sheppard LJ, Sutton MA, Fowler D, Munro RC; Tang S, Wilson D

10 (1998). The relationship between nitrogen deposition, species composition and foliar nitrogen

11 concentrations in woodland flora in the vicinity of livestock farms. Environmental Pollution

$12102(\mathrm{~S} 1): 41-48$.

13 Pitman R, Vanguelova EI, Benham S (2010). Effects of phytophagous insects on the nutrient

14 concentrations and fluxes through forest stands in the UK Level II network. Science of the

15 Total Environment 409 (1): 169-181.

16 Prescott CE (2002). The influence of the forest canopy on nutrient cycling. Tree physiology

$17 \quad 22: 1193-1200$.

18 R core team (2014). R: A Language and Environment for Statistical Computing. R

19 Foundation for Statistical Computing Vienna, Austria. http://www.R-project.org

20 Rennenberg H, Kreutzer K, Papen H, Weber P (1998). Consequences of high loads of 21 nitrogen for spruce (Picea abies) and beech (Fagus sylvatica) forests. New Phytologist $22 \quad$ 139:71-86.

23 Rennenberg H, Gessler A (1999). Consequences of N deposition to forest ecosystems- Recent 24 results and future research needs. Water, Air and Soil Pollution 116: 47-64.

25 RoTAP (2012). Review of Transboundary Air Pollution: Acidification, Eutrophication, 
1 Ground Level Ozone and Heavy Metals in the UK. Contract Report to the Department for

2 Environment, Food and Rural Affairs. Centre for Ecology \& Hydrology.

3 Sah SP, Brumme R. (2003) Natural ${ }^{15} \mathrm{~N}$ abundance in two nitrogen forest ecosystems at

4 Solling, Germany. Journal of Forest Science 49: 515-522.

5 Saurer M, Cherubini P, Ammann M, De Cinti B, Siegwolf RTW (2004). First detection of

6 nitrogen from $\mathrm{NO}_{\mathrm{x}}$ in tree rings: $\mathrm{a}^{15} \mathrm{~N} /{ }^{14} \mathrm{~N}$ study near a motorway. Atmospheric Environment $7 \quad 38: 2779-2787$.

8 Savard MM, Bégin C, Smirnoff A, Marion J Rioux-Paquette E (2009). Tree-Ring Nitrogen

9 Isotopes Reflect Anthropogenic $\mathrm{NO}_{\mathrm{x}}$ Emissions and Climatic Effects. Environmental Science 10 and Technology 43 (3): 604-609.

11 Schwarz MT, Oelmann Y, Wilcke W (2011). Stable N isotope composition of nitrate reflects

$12 \mathrm{~N}$ transformations during the passage of water through a montane rain forest in Ecuador.

13 Biogeochemistry 102 (1-3): 195-208.

14 Schulze E-D (2006). Biological control of the terrestrial carbon sink, Biogeosc. 3(2): 14715166.

16 Teuber M, Papen H, Gasche R, Eßmüller TH Geßler A (2007). The apoplast of Norway 17 spruce (Picea abies) needles as habitat and reaction compartment for autotrophic nitrifiers. In: 18 B. Sattelmacher and W.J. Horst (eds.), The Apoplast of Higher Plants: Compartment of 19 Storage, Transport and Reactions 405-425.

20 Tobari Y, Koba K, Fukushima K, Tokuchi N, Ohte N, Tateno R, Toyoda S, Yoshioka T, 21 Yeatman SG, Spokes LJ, Dennis PF, Jickells TD (2001). Compositions of aerosol nitrogen 22 isotopic composition at two polluted coastal sites. Atmospheric Environment 35: 1307-1320.

23 Vanguelova EI, Pitman R (2009). Impact of N deposition on soil and tree biochemistry in 24 both broadleaved and coniferous stands in the UK. In "6th International Symposium on 
1 Ecosystem Behaviour BIOGEOMON 2009", Liisa Ukonmaanoho, Tiina M. Nieminen and

2 Mike Starr (eds.), ISSN 1795-150X, pp.184.

3 Vanguelova EI, Benham S, Pitman R, Moffat A, Broadmeadow M, Nisbet T, Durrant D,

4 Barsoum N,Wilkinson M, Bochereau F, Broadmeadow S, Hutchings T, Crow P, Durrant-

5 Huston T, Taylor P (2010). Chemical fluxes in time through forest ecosystems in the UK -

6 soil response to pollution recovery. Environmental Pollution 158 (5): 1857-1869.

7 Vanguelova $\mathrm{E}$ and Pitman $\mathrm{R}$ (2011). Impacts of $\mathrm{N}$ inputs on forests and forest soil 8 biogeochemistry in Great Britain. Paper in proceedings of "Nitrogen \& Global Change - Key

9 findings - future challenges", April 11-15, 2011, Edinburgh, UK.

10 Vanguelova EI, Reynolds B, Nisbet T, Godbold D (2011). The cycling of pollutants in non-

11 urban forested environments. In: Levia DF, Carlyle-Moses DE, Tanaka T (Eds.), Forest

12 Hydrology and Biogeochemistry: Synthesis of Past Research and Future Directions.

13 Ecological Studies Series, No. 216, Springer-Verlag, Heidelberg, Germany, 2011, DOI

14 10.1007/978-94-007-1363-5_34.

15 Vitousek P, Aber J, Howarth RW, Likens GE, Matson PA, Schindler DA, Schlesinger WH, 16 Tilman GD (1997). Human Alteration of the Global Nitrogen Cycle: Causes and 17 Consequences. Issue in Ecology 1: 1-16.

18 Wuyts K, Adriaenssens S, Staelens J, Wuytack, Wittenberghe SV, Boeckx P, Samson R, 19 Verhryen K (2015). Contributing factors in foliar uptake of dissolved inorganic nitrogen at 20 leaf level. Science of Total Environment 505: 992-1002.

21 Yoshida N (2010). Contribution of atmospheric nitrate to stream-water nitrate in Japanese 22 coniferous forests revealed by the oxygen isotope ratio of nitrate. Rapid Commun. Mass 23 Spectrom 24: 1281-1286. 
1 Young ED, Galy A, Nagahara H (2002). Kinetic and equilibrium mass-dependent isotope

2 fractionation laws in nature and their geochemical and cosmochemical significance, 3 Geochimica Cosmochimica Acta 66 (6): 1095-1104. 
1 Table 1. Site, climatic and atmospheric $N_{d e p}$ information of the four forest stands included in the study. Climate data are mean values calculated 2 over the years 1960-2010 and deposition data are mean values over a number of years (e.g., Alice Holt - Beech site- 2006-2008; Rogate-Scots

3 pine site - 2010-2012; Thetford Scots pine site - 1995-2010; Thetford-Beech site - 2006-2008).

\begin{tabular}{|c|c|c|c|c|c|c|c|c|c|}
\hline Site & Species & $\begin{array}{l}\text { Stand } \\
\text { age }\end{array}$ & $\begin{array}{l}\text { Soil type } \\
\text { (WRB, 2006) }\end{array}$ & $\begin{array}{l}\text { Precipitation } \\
(\mathbf{m m})\end{array}$ & $\begin{array}{c}\mathbf{T} \\
\left({ }^{\circ} \mathbf{C}\right)\end{array}$ & $\begin{array}{c}\mathrm{NH}_{4}^{+} / \mathrm{NO}_{3}^{-} \\
\operatorname{Dry}^{-} \\
\left(\mathrm{kg} \mathrm{ha}^{-1} \mathrm{yr}^{1}\right)\end{array}$ & $\begin{array}{c}\mathrm{NH}_{4}^{+} / \mathrm{NO}_{3}^{-} \\
\text {Wet } \\
\left(\mathrm{kg} \mathrm{ha}^{-1} \mathrm{yr}^{-1}\right)\end{array}$ & $\begin{array}{c}\text { totN dep } \\
\text { Dry/Wet } \\
\left(\mathrm{kg} \mathrm{ha}^{-1} \mathrm{yr}^{-1}\right)\end{array}$ & $\begin{array}{c}\text { Tot } N_{d e p} \\
\left(\mathrm{~kg} \mathrm{ha}^{-1} \mathrm{yr}^{-1}\right)\end{array}$ \\
\hline Alice Holt & Beech & 70 & Cambisol & 800 & 11.6 & $2.7 / 0.2$ & $3.7 / 3.2$ & $2.9 / 6.9$ & 9.8 \\
\hline Rogate & Scots pine & 60 & Cambisol & 800 & 11.6 & $4.1 / 0.6$ & $3.1 / 2.9$ & $4.8 / 5.9$ & 10.7 \\
\hline \multirow[b]{2}{*}{ Thetford } & Beech & 70 & \multirow[t]{2}{*}{ Arenosol } & \multirow[b]{2}{*}{600} & \multirow[b]{2}{*}{11.3} & $4.9 / 4.6$ & $7.5 / 2.7$ & $9.5 / 10.2$ & 19.7 \\
\hline & Scots pine & 45 & & & & $3.2 / 1.8$ & $5 / 3.3$ & $5.0 / 8.4$ & 13.4 \\
\hline
\end{tabular}


Table 2. Mean values of the $\mathrm{NH}_{4}{ }^{+}$and $\mathrm{NO}_{3}{ }^{-}$fluxes measured over the 6 months considered in this study, i.e., June to November 2011) at the two LN sites (e.g. Alice Holt - Beech stand; Rogate-Scots pine stand) and HN sites ( Thetford Scots pine stand; Thetford-Beech stand).

\begin{tabular}{l|l|c|c}
\hline Site & Species & $\begin{array}{c}\mathbf{N H}_{\mathbf{4}}{ }^{+} / \mathbf{N O}_{\mathbf{3}}{ }^{-} \\
\mathbf{R F} \\
\left(\mathbf{k g ~ h a}^{-1} \mathbf{~ y r}\right.\end{array}$ & $\begin{array}{c}\mathbf{N H}_{\mathbf{4}}{ }^{+} / \mathbf{N O}_{\mathbf{3}}{ }^{-} \\
\mathbf{T F} \\
\left(\mathbf{k g ~ h a}^{-1} \mathbf{~} \mathbf{~ r}^{-\mathbf{1}}\right)\end{array}$ \\
\hline Alice Holt & Beech & $0.8 / 0.7$ & $0.2 / 0.3$ \\
\hline Rogate & Scots pine & $0.5 / 0.5$ & $0.3 / 0.3$ \\
\hline \multirow{2}{*}{ Thetford } & Beech & $1.6 / 0.5$ & $4.9 / 1.0$ \\
\cline { 2 - 4 } & Scots pine & $0.6 / 0.5$ & $1.8 / 1.9$ \\
\hline
\end{tabular}


Table 3. $\Delta^{17} \mathrm{O}$ values for $\mathrm{NO}_{3}{ }^{-}$in rainfall (RF) and throughfall (TF) water samples collected during 2011 growing season at the HN sites. Water sampled in June-August and SeptemberNovember was combined for isotope analyses. This was necessary also for RF water samples collected at the Scots pine and beech stands (see Materials and Methods for more details).

\begin{tabular}{|c|c|c|c|c|}
\hline \multirow[t]{2}{*}{ Site } & \multirow[t]{2}{*}{ Forest stand } & \multirow[t]{2}{*}{ Months } & \multicolumn{2}{|c|}{$\Delta^{17} \mathrm{O}(\%)$} \\
\hline & & & TF & RF \\
\hline \multirow{4}{*}{$\begin{array}{l}\text { Thetford } \\
\text { (HN) }\end{array}$} & \multirow[t]{2}{*}{ Scots pine } & June-August & 21.72 & 24.99 \\
\hline & & September-November & 20.71 & 26.06 \\
\hline & \multirow[t]{2}{*}{ Beech } & June-August & 10.06 & 26.06 \\
\hline & & September-November & 10.98 & 24.99 \\
\hline
\end{tabular}


Table 4. Range of $\delta^{15} \mathrm{~N}$ and $\delta^{18} \mathrm{O}$ values for $\mathrm{NO}_{3}{ }^{-}$and $\mathrm{NH}_{4}{ }^{+}$in monthly rainfall samples from mainly remote upland areas in north and west mainland Britain (Heaton et al, 1997; Curtis et al., 2012; Heaton, unpublished data)

\begin{tabular}{l|c|c|c|c}
\hline Isotope & Total range & Mean & Interquartile range & N \\
\hline$\delta^{15} \mathrm{~N}-\mathrm{NO}_{3}$ & $-8.2 \%$ to $+4.3 \%$ o & $-2.0 \%$ o & $-3.8 \%$ to $-0.5 \%$ o & 117 \\
\hline$\delta^{18} \mathrm{O}-\mathrm{NO}_{3}$ & $+50 \%$ o to $+82 \%$ o & $+69 \%$ o & $+65 \%$ to $+73 \%$ o & 117 \\
\hline$\delta^{15} \mathrm{~N}-\mathrm{NH}_{4}$ & $-12.6 \%$ to $+2.8 \%$ o & $-4.3 \%$ o & $-6.2 \%$ to $-2.8 \%$ o & 86 \\
\hline
\end{tabular}


Figure 1. $\mathrm{NO}_{3}-\mathrm{N}$ and $\mathrm{NH}_{4}-\mathrm{N}$ in Rainfall (RF) and Throughfall (TF) Scots pine and beech forests at the LN (i.e., Alice and Holt and Rogate, respectively) and HN (i.e., Thetford). Each symbol represents the mean $( \pm \mathrm{SE})$ for ions concentrations measured in water samples collected from June until November 2011.

Figure 2. A) $\delta^{15} \mathrm{~N}$ values of $\mathrm{N}^{-N_{H}}{ }_{4}^{+}$in Rainfall (RF) and Throughfall (TF) Scots pine and beech at the LN (i.e., Alice and Holt and Rogate, respectively) and HN (i.e., Thetford). Each symbol represents the mean $( \pm \mathrm{SE})$ for isotope measurements carried out in water samples collected from June-August and September- November 2011. B) Differences (mean \pm CI) between TF and RF for $\delta^{15} \mathrm{~N}_{-} \mathrm{NH}_{4}^{+}$values measured at the $\mathrm{LN}$ and $\mathrm{HN}$ sites, without distinguishing between tree species. Please note that the two symbols for the $\delta^{15} \mathrm{~N}-\mathrm{NO}_{3}{ }^{-}$ values measured in TF for the two species overlap (i.e., Scots pine $=-1.76 \pm 0.17 \%$; beech $=$ $-1.72 \pm 1.25 \%$ )

Figure 3. A) $\delta^{15} \mathrm{~N}$, B) $\delta^{18} \mathrm{O}$ and C) $\Delta^{17} \mathrm{O}$ values of $\mathrm{N}-\mathrm{NO}_{3}$ in rainfall (RF) and throughfall (TF) for Scots pine and beech at the LN (i.e., Alice and Holt and Rogate, respectively) and HN (i.e., Thetford). Each symbol represents the mean ( \pm SE) for isotope measurements carried out in water samples collected from June-August and September-November 2011. Differences (diff., mean $\pm \mathrm{CI}$ ) between $\mathrm{TF}$ and $\mathrm{RF}$ for $\left.\mathbf{D}) \delta^{15} \mathrm{~N}-\mathrm{NO}_{3}{ }^{-}, \mathbf{E}\right) \delta^{18} \mathrm{O}_{-} \mathrm{NO}_{3}{ }^{-}$and $\mathbf{F}$ ) $\Delta^{17} \mathrm{O}$ values measured at the $\mathrm{LN}$ and $\mathrm{HN}$ sites, without distinguishing between tree species.

Figure 4. $\delta^{15} \mathrm{~N}$ vs. $\delta^{18} \mathrm{O}$ and $\delta^{18} \mathrm{O}$ vs. $\Delta^{17} \mathrm{O}$ for Scots pine (A and $\mathbf{B}$, respectively) and beech (C and D, respectively) measured in RF and TF. Each symbol represents the mean ( \pm SE) for isotope measurements carried out in water samples collected from June-August and September- November 2011 at the LN (Rogate and Alice Holt for the Scots pine and Beech, 
respectively) and HN (Thetford, for both tree species). Arrows depict dramatic changes from RF to TF for the isotope values.

Figure 5. A) Mean $( \pm \mathrm{SD})$ of the $\mathrm{NO}_{3}{ }^{-}$fraction derived from the atmosphere $\left(\mathrm{f}_{A t m}\right)$ and nitrification $\left(\mathrm{f}_{B i o}\right)$ measured for the June-August and September-November months at the two $\mathrm{HN}$ forest stands. B) Fraction of $\mathrm{NO}_{3}{ }^{-}$derived from nitrification $\left(\mathrm{f}_{B i o}\right)$ for the two sampling periods (i.e., June-August and September-November) at the $\mathrm{HN}$ forest sites. 


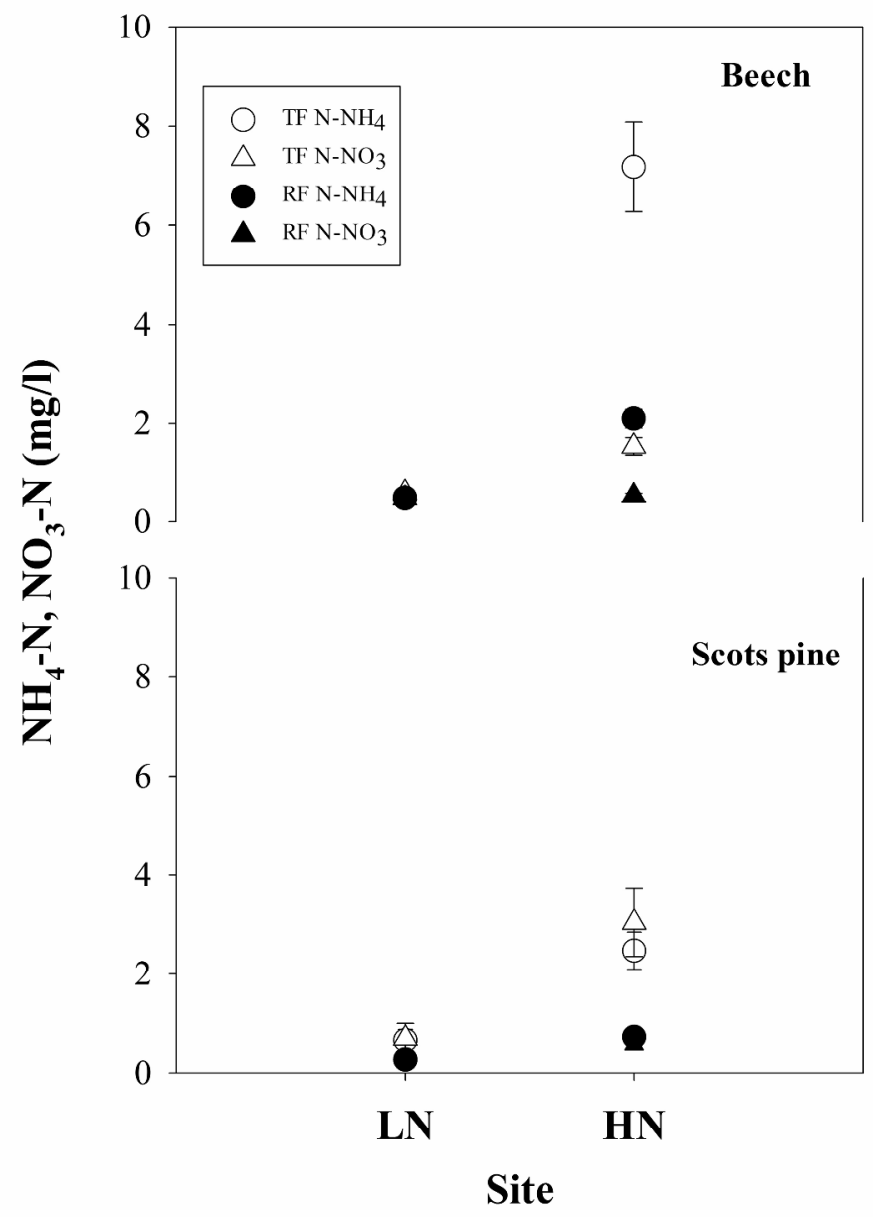

Figure 1. NO3-N and NH4-N in Rainfall (RF) and Throughfall (TF) Scots pine and beech forests at the LN (i.e., Alice and Holt and Rogate, respectively) and HN (i.e., Thetford). Each symbol represents the mean ( \pm SE) for ions concentrations measured in water samples collected from June until November 2011. $298 \times 411 \mathrm{~mm}(300 \times 300$ DPI) 

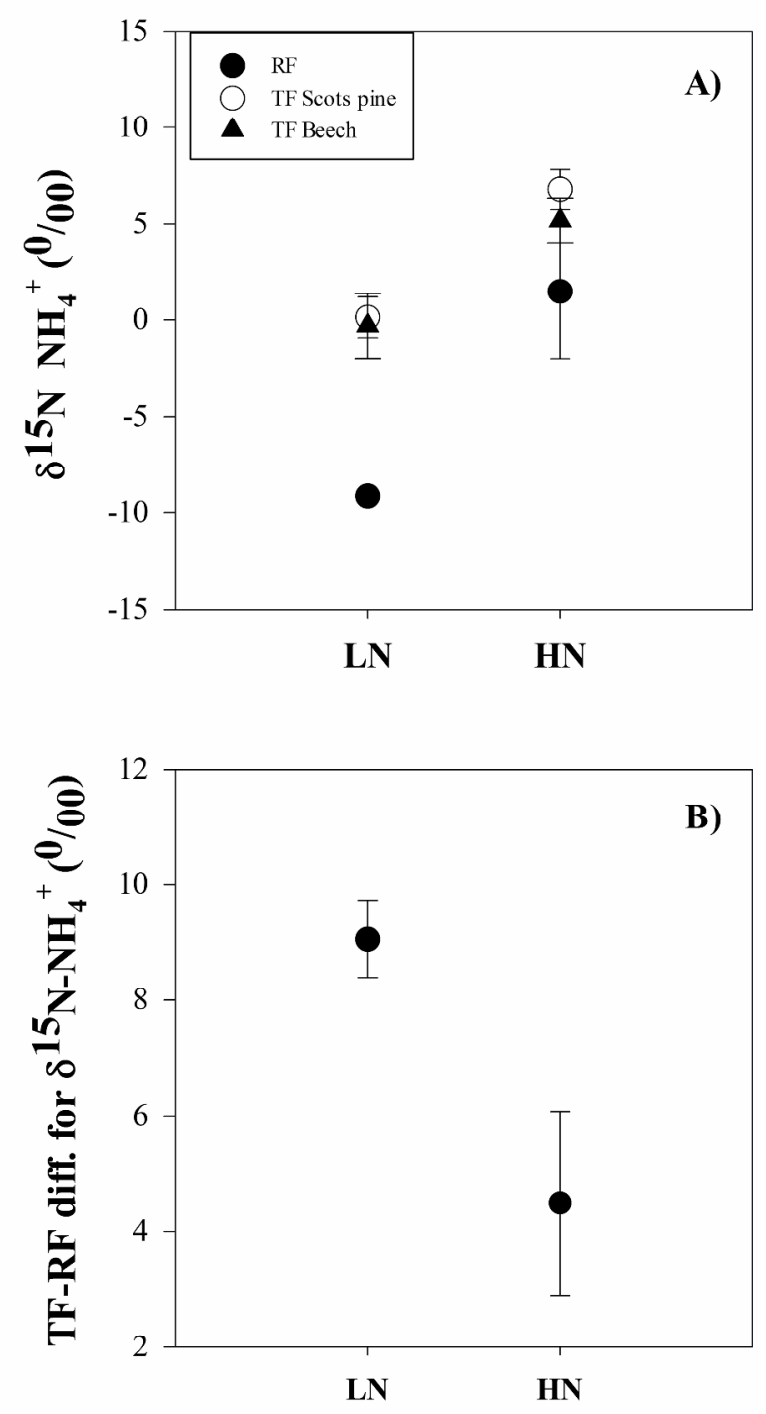

Site

Figure 2. A) $\delta 15 \mathrm{~N}$ values of $\mathrm{N}-\mathrm{NH} 4+$ in Rainfall (RF) and Throughfall (TF) Scots pine and beech at the LN (i.e., Alice and Holt and Rogate, respectively) and HN (i.e., Thetford). Each symbol represents the mean ( \pm $\mathrm{SE}$ ) for isotope measurements carried out in water samples collected from June-August and SeptemberNovember 2011. B) Differences (mean \pm CI) between TF and RF for $\delta 15 \mathrm{~N}-\mathrm{NH} 4+$ values measured at the LN and HN sites, without distinguishing between tree species. Please note that the two symbols for the $\delta 15 \mathrm{~N}-$ NO3- values measured in TF for the two species overlap (i.e., Scots pine $=-1.76 \pm 0.17 \%$; beech $=-1.72$ $\pm 1.25 \%$ o ).

$309 \times 506 \mathrm{~mm}$ (300 x 300 DPI) 

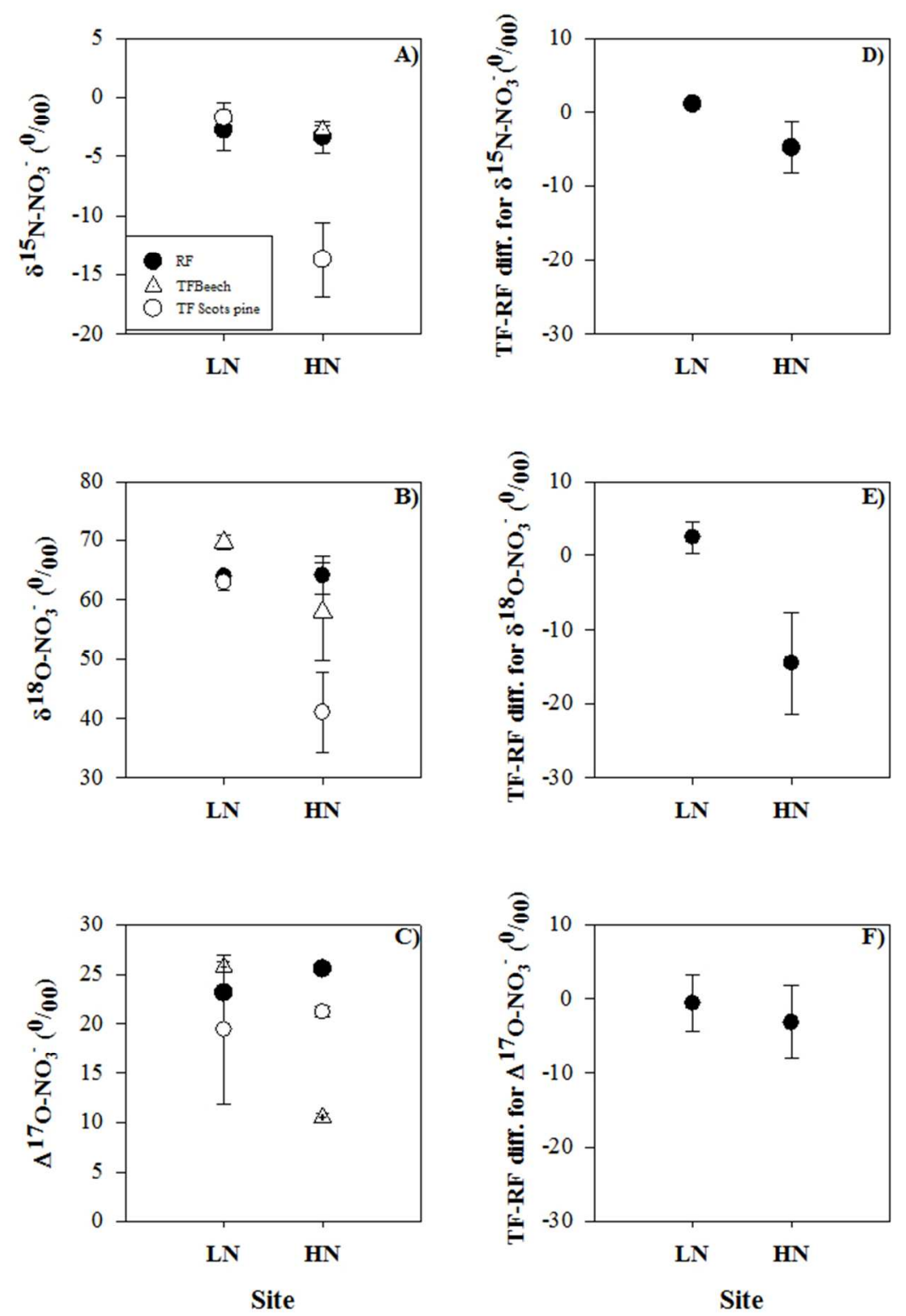

Figure 3. A) $\delta 15 \mathrm{~N}, \mathrm{~B}) \delta 180$ and C) $\Delta 170$ values of $\mathrm{N}-\mathrm{NO} 3$ in rainfall (RF) and throughfall (TF) for Scots pine and beech at the LN (i.e., Alice and Holt and Rogate, respectively) and HN (i.e., Thetford). Each symbol represents the mean $( \pm S E)$ for isotope measurements carried out in water samples collected from JuneAugust and September-November 2011. Differences (diff., mean \pm CI) between TF and RF for D) $\delta 15 N-$ NO3-, E) $\delta 180-N O 3-$ and F) $\Delta 170$ values measured at the $L N$ and $H N$ sites, without distinguishing between tree species.

$132 \times 190 \mathrm{~mm}(136 \times 136 \mathrm{DPI})$ 

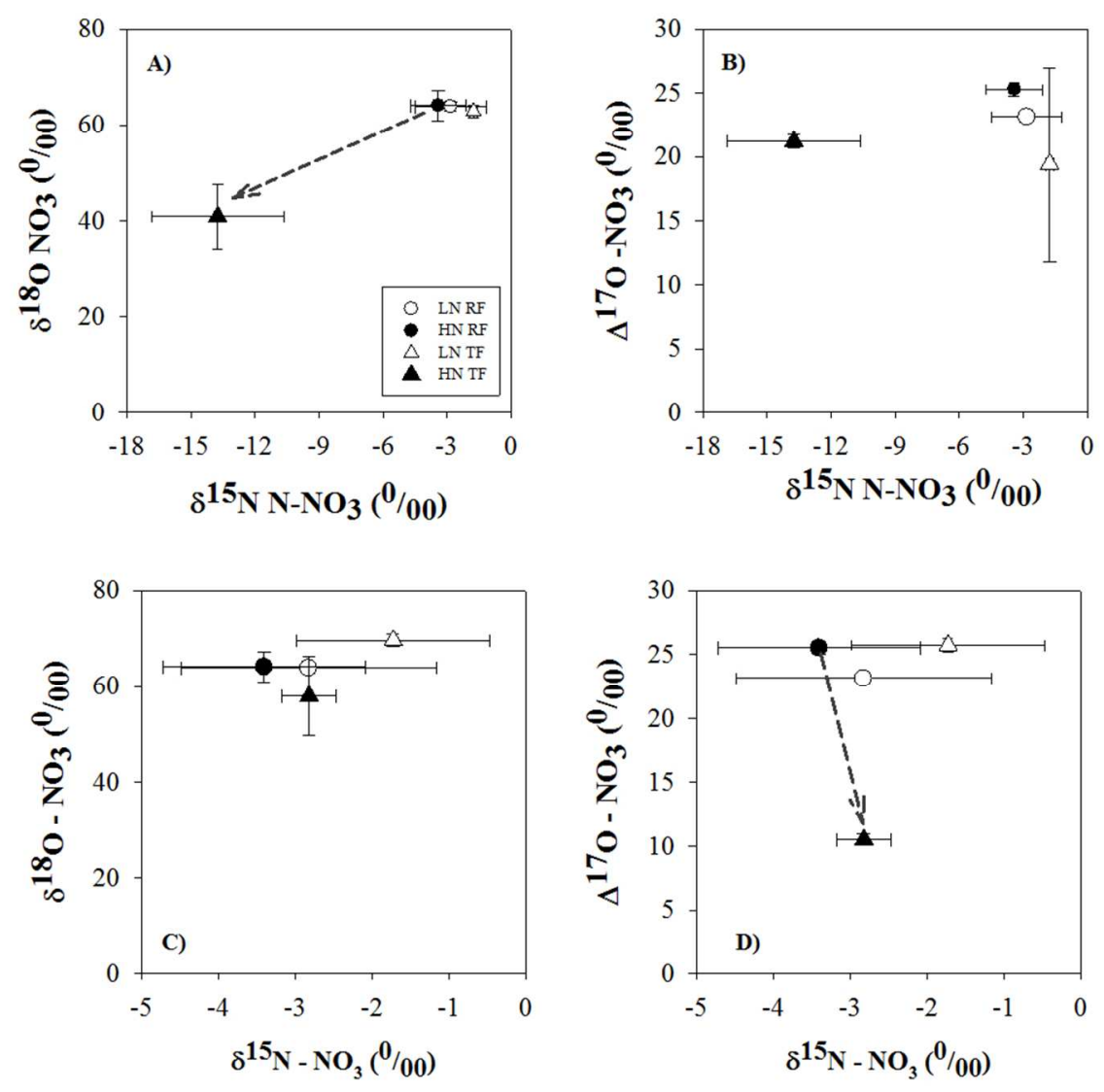

Figure $4 . \delta 15 N$ vs. $\delta 180$ and $\delta 180$ vs. $\Delta 170$ for Scots pine ( $A$ and $B$, respectively) and beech (C and D, respectively) measured in RF and TF. Each symbol represents the mean ( $\pm \mathrm{SE}$ ) for isotope measurements carried out in water samples collected from June-August and September- November 2011 at the LN (Rogate and Alice Holt for the Scots pine and Beech, respectively) and HN (Thetford, for both tree species). Arrows depict dramatic changes from RF to TF for the isotope values. $266 \times 355 \mathrm{~mm}(96 \times 96 \mathrm{DPI})$ 

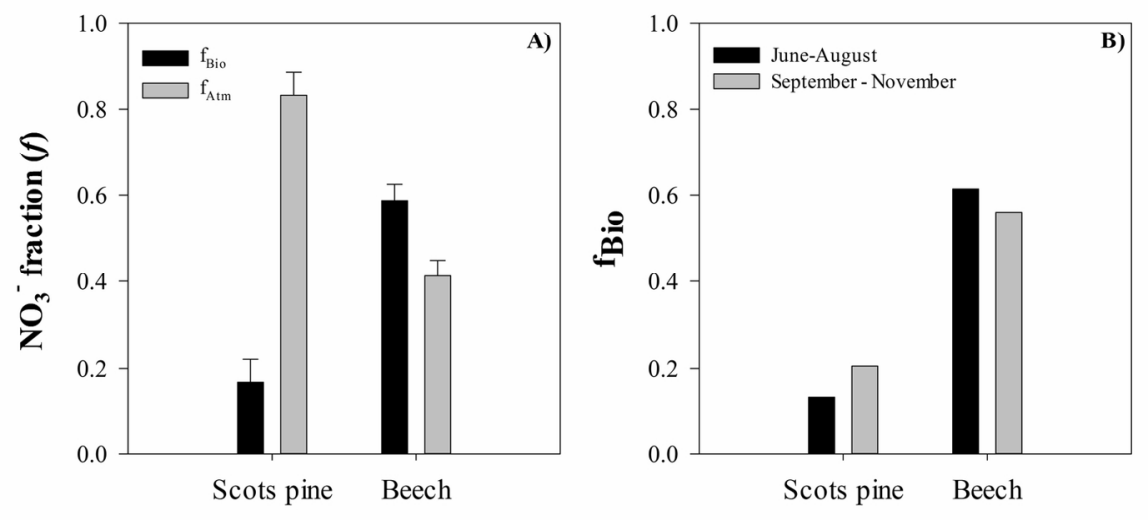

\section{HN forest stand}

Figure 5. A) Mean ( \pm SD) of the NO3- fraction derived from the atmosphere (fAtm) and nitrification (fBio) measured for the June-August and September-November months at the two HN forest stands. B) Fraction of NO3- derived from nitrification (fBio) for the two sampling periods (i.e., June-August and SeptemberNovember) at the HN forest sites. $148 \times 81 \mathrm{~mm}(300 \times 300 \mathrm{DPI})$ 